\title{
歯周病の診断に関する細菌学的研究
}

\author{
神山章 \\ 大阪大学歯学部口腔治療学講座 \\ (指導 : 岡田 宏教授) \\ (昭和 63 年 12 月 26 日受付)
}

\section{Microbiological and Serological Investigation of Periodontal Disease Activity}

\begin{abstract}
Akira KOHYAMA
Department of Periodontology and Endodontology, Osaka University Faculty of Dentistry
\end{abstract}

(Director : Prof. Hiroshi OKADA)

If disease activity in periodontal disease can be determined, the therapeutic measures of periodontitis may become diverse and different from patient to patient. The purpose of the present study was to evaluate the usefullness of microbiological and serological examination of periodontopathic bacteria in detecting destructive periodontal disease activity.

One hundred and forty-eight sites in 52 subjects with moderate to severe periodontitis were studied clinically. Clinical parameters included plaque index, gingival index, probing depth, bleeding on probing and percent bone loss as measured radiographically. Subgingival plaque of whole sites was investigated microbiologically by means of indirect fluorescentantibody technique with rabbit antibodies against Actinomyces viscosus, Actinobacillus actinomycetemcomitans (2 serotypes), Eikenella corrodens, Fusobacterium nucleatum, Bacteroides ginginalis and Bacteroides intermedius. The levels of serum IgG antibody to these organisms were determined by enzyme-linked immunosorbent assay with whole cell prepartions. Thirty-two of 52 subjects were instructed in oral hygiene and received several sessions of scaling and root planing. The clinical, bacteriological and sero- logical assessments were also performed after periodontal therapy. Active disease site was defined as the site of which clinical status did not be improved even after periodontal treatment.

$B$. gingivalis, $B$. intermedius and $A$. viscosus were detected in $80 \%$ of periodontal lesions, and the proportion of $B$. gingivalis was the highest among six bacterial species tested. A. actinomycetemcomitans, $E$. corrodens and $F$. nucleatum were found only occasionally and in low numbers. The proportion of $B$. gingivalis was higher in severely inflamed sites than in clinically healthy sites. B. gingivalis and $B$. intermedius are rarely found in treated periodotitis sites, while the proportion of $A$. viscosus was slightly increased after theatment.

Sera of the pre-treatment patients demonstrated significantly higher antibody levels to $B$. gingivalis and significantly lower levels to $A$. viscosus than those of healthy persons. Antibody levels reactive with other four species in the patients did not significantly differ from the levels in healthy persons. After periodontal therapy, antibody levels to $B$. gingivals, B. intermedius and A. actinomycetemcomitans (serotype a) significantly decreased and the levels to

本論文の要旨は, 第 30 回秋季日本歯周病学会総会 (1987 年 10 月 30 日), 第 34 回大阪大学歯学会総会 (1987 年 11 月 28 日), お よび第 88 回日本歯科保存学会春季学会（1988年 5 月 27 日）において発表した。 
A. viscosus increased to a slight degree.

B. gingivalis was found more frequently in diseaseactive sites than in disease-inactive sites. The proportions of other bacterial species in disease-active sites did not differ from those in disease-inactive sites.
The results of the present investigation suggest that monitoring $B$. gingivalis in subgingival plaque and serum IgG antibody titer against this organism may aid in the description and adequet treatment of the periodontal disease.

Key words : Periodontopathic bacteria, Indirect flurescent-antibody technique, Serum IgG titer, Disease activity, Re-evaluation

要旨 : 歯周病における診断指標を探求する目的で, 歯周炎患者の初期治療前後における歯肉縁下プラーク中の 6 種 類の歯周病原性細菌の検出とそれらに対する血清 IgG 抗体価の変動を調べた。臨床的に炎症程度が高いと判断され た部位のプラーク中には Bacteroides gingivalis $(\mathrm{Bg})$ が高い比率で存在していた。初診時に約 $80 \%$ の歯周ポケット から検出された $\mathrm{Bg}$ や Bacteroides intermedius (Bi) は，初期治療によって検出率および検出部位率が有意に減少し た。そして，抗 $\mathrm{Bg}$ 抗体価および抗 Bi 抗体価は，初期治療後には初診時と比較して有意に減少した。さらに初期治 療に対する臨床指数の改善度によって推定した疾病活性度と細菌検出率との関係を検討した結果, 改善度の高い部位 では低い部位よりも，初期治療後の Bg の検出率が有意に低かった。以上より，歯周治療に際してプラーク中の Bg の検出率と抗 $\mathrm{Bg}$ 抗体価が診断指標の一つとなる可能性が示唆された。

索引用語 : 歯周病原性細菌, 間接螢光抗体法, 血清抗体価, 疾病活性度, 再評価

\section{緒言}

微生物が感染すると, 通常は, 生体の免疫反応が作動 し, その結果抗体が産生される1)。感染症の解明には, 感染病原体を検出し, 同定することが第一義的に必要で あるが, 疾病が治癒あるいは慢性化しても, 抗体産生や 免疫反応が持続することがあり，何らかの形で症状の経 過に関与すると考えられる。したがって, 感染症の診断 と治療に際して, 病原微生物ならびにそれに対する宿主 側の特異抗体の検出は，合理的な原因除去療法を施すう えで必要なことである。

歯周炎は歯肉縁下プラーク細菌によって惹起される炎 症性疾患であり ${ }^{2 \sim 5)}$, 宿主はこれらの細菌に対し種々の 生体反応を起こしている。それゆえ, 歯周炎においても, ポケット内細菌に基盤を置く治療体系が確立できれば, より効果的な歯周治療が行えると期待される。

近年，歯周病原性細菌としてグラム陰性嫌 気 性桿 菌

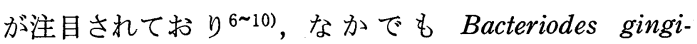
valis $^{11 \sim 13)}$ および Actinobacillus actinomycetemcomit$a n s^{14 \sim 16)}$ が，歯周病の病型と特異的に関連するという報 告が数多くある。また, 歯周炎の進行に伴う歯肉縁下細 菌叢の変動や17 19), 歯周治療による歯肉縁下細菌叢の変 動20 22), さらに歯周病原性細菌に対する血清抗体価の変 動と歯周治療との関連性 ${ }^{23,24)}$ についての研究などから,
歯周炎にある種の特定細菌が関連していることが示唆さ れている。しかしながら現在までのところ，これらの細 菌が歯周炎を決定づける真の病原菌かどうかは確定され ておらず，歯周治療における診断指標として利用し得る までにはいたっていない。

病原性細菌の検查法は, 次の 2 つに大別される。すな わち，患者より採取した検体から，顕微鏡的観察などに より直接細菌を検出する方法と, 病巣から細菌を分離培 養し，菌種の同定および感受性試験を行う方法である。 塗沫染色標本の検鏡は従来から行われている細菌の迅速 検査であり，現在でも場合によっては有用である。例え ば，チールネルゼン染色法による喀痰の塗沫標本中の抗 酸菌の証明は，抗結核剂使用開始の指標となる。しかし 多くの場合, 感染症の確定診断は原因菌の分離同定によ って判断される。そして，これが不可能な場合，たとえ ば梅毒トレポネーマなどの培養不可能な菌については血 中抗体価の測定が行われる。また, ASLO などによる連 鎖球菌感染症, Widal 反応によるサルモネラ感染症の検 査など, 個々の感染症について多くの抗体価測定法が検 討されている。一般には，抗原を換えるだけで同じ手法 により特異抗体の測定が可能な方法として, 補体結合反 応, 間接螢光抗体法, 酵素免疫測定法 (enzyme-linked immunosorbent assay；ELISA) などが挙げられる。

歯科領域において，暗視野めるいは位相差顕微鏡でプ ラークを直接観察する方法は，チェアーサイドで迅速に 
行えるらえ，培養法では検出できないスピロヘータや運 動性桿菌なども検出することができる。しかし，この方 法は細菌をその形態と運動性によって分類できるだけ で，菌種の同定は不可能である。一方，培養法を用いた 検索によれば，分離された菌株の大部分が，その分類さ れるべき種属を決定できるが，場合によっては菌叢中に 存在していた細菌のうち半分近くが発育してこなかった り，発育しても同定基準にあてはまらず，分類不能な菌 が存在し，検索できる細菌は細菌叢の $70 \%$ 程度である といわれている25)。

歯肉縁下プラークを構成する細菌種の検索は，現在， 主として培養法により行われているが，上記の問題点以 外に，培養や同定に多くの時間と労力および経費が必要 であるため，臨床の場ではより迅速かつ簡便な方法の開 発が求められている。

本研究では間接螢光抗体法により歯肉縁下プラーク中 の特定細菌を直接検出する方法と，それらの特定細菌に 対する患者末梢血中の特異抗体価を ELISA 法により測 定する実験系を確立し，歯周初期治療前後の歯周炎患者 の歯肉縁下プラークおよび血清を分析して，それらと種 々の臨床指数との関倸を統計学的に解析する事により， 歯周病に掞ける診断指標となり得る因子を検討した。

\section{材料および方法}

\section{1. 被験者}

大阪大学歯学部附属病院歯周病診療室を受診し, 中等 度以上の辺縁性歯周炎之診断され，全身的な異常を認め ない 52 名（年齢 21 歳から 53 歳，平均 38.9 歳，男性 23 名, 女性 29 名) を被験者とした。プロービングにより 4 $\mathrm{mm}$ 以上の歯周ポケットの深さを示す 128 部位と, 歯肉 溝深さが $3 \mathrm{~mm}$ 以下である 20 部位, 合計 148 部位を被 験部位として選択し, 初診時に臨床所見を観察するとと もに, 歯肉縁下プラークの細菌学的検查と血清抗体価の 测定を行った。その後, 32 名の患者の 97 部位について は，刷掃指導，スケーリング，ルートプレーニング等を 中心とした初期治療を施した後, 再度, 臨床所見の観察, 歯肉縁下プラークの細菌学的検查挍よび血清抗体価の測 定を行った。なお，今回の被験者には，いわゆる典型的 な限局型若年性歯周炎患者は含まれていない。

\section{2. 臨床所見の観察}

被験部位の病態を以下の臨床指数を測定することによ って示した。

（1）プラーク指数 (P 1 I ) : Silness と Lö $\mathrm{e}^{26)}$ の基準
に従い，プラーク付着がみられないものを 0 ，探針の擦 過により薄膜状プラークが判明するものを 1 , 中等度の プラーク付着が肉眼で観察されるものを 2 , 歯面に多量 のプラークが存在するものを 3 として評何した。

（2）歯肉炎指数 (GI)：Löe と Silness ${ }^{27)}$ の基準に従 い, 健常歯肉を 0 , 歯肉に軽度の炎症が存在するものを 1, 歯肉に中等度の炎症がみられ，歯周ポケットを探針で 触れると出血するものを 2 , 自然出血のみられる高度の 炎症歯肉を 3 と評価した。

(3) ポケット梁さ (PD) : カラーコードプローベ(CP12, Hu-Friedy, USA) を用いて約 $20 \mathrm{~g}$ の測定圧で行い, $1 \mathrm{~mm}$ 単位まで計測した。

（4）プロービング時つ出血の有無（BP）：PD を測定 した後 30 秒以内に出血が認められたものを $(+)$, 出血 しなかったものを（一）とした。

（5）骨吸収率 (BLS)：Schei ら ${ }^{28)}$ の方法により，骨吸 収メジャーを用いて，デンタルX線写真上でセメントエナメル境より歯槽骨頂までの距離の，歯根長に対する 比率を求めた。

3. 試料の採取

1） 歯肉縁下プラークの採取

被験部位の歯肉縁上プラークを綿球で除去した後, ペ ーパーポイント(ジョンソン・エンド・ジョンソン $\mathrm{KK}$, 東京）を歯肉溝底部まで挿入し, 30 秒間静置した。その 後, ペーパーポイントを $100 \mu l$ の滅菌蒸留水中に浸漬 し, voltex mixer にて 10 秒間擋找して, プラーク浮遊 液を作製した。

2）血清の調製

被験者の肘正中静脈より静脈血 $5 \mathrm{~m} l$ を採取して血清 を分離した後, $0.01 \%$ の濃度になるようにチメロサール (Sigma Chemical Co., St. Louis, Mo., USA) を加え, 測定に供するまで $-20^{\circ} \mathrm{C}$ で保存した。なお，歯周炎非 䍜患者として， $4 \mathrm{~mm}$ 以上の歯周ポケットが存在せず, 口腔衛生管理の良好な者 32 名 (20 歳 39 歳, 平均 28.7 歳)の血清（健常者血清）を得て, 患者血清と比較した。

\section{4. 供試菌株とその培養}

Actinomyces viscosus ATCC 19246, T $14 \mathrm{~V}$ および Nyl, Actinomyces naeslundii ATCC 12104, A. actinomycetemcomitans ATCC 29522 および ATCCC 29523, Eikenella corrodens 1073，1080 おすよ゙ 375, Fusohacterium nucleatum 1436, 325, 364, 398, 1439 および $1440, B$. gingivalis 381, ATCC 33277, H および 21, Bacteroides intermedius ATCC 33563 および ATCC 25611, Bacteroides gracilis 21, Bacteroides ureolyticus 32 , Streptococ- 
表 1 吸収操作を行った抗血清と細菌の組み合わせ

\begin{tabular}{cccccccc}
\hline 抗血清 & 抗 $\mathrm{Av}$ & 抗 $\mathrm{Aa} 2$ & 抗 $\mathrm{Aa} 3$ & 抗 $\mathrm{Ec}$ & 抗 $\mathrm{Fn}$ & 抗 $\mathrm{Bg}$ & 抗 $\mathrm{Bi}$ \\
細菌 & $\mathrm{Bi}$ & $\mathrm{Aa} 3$ & $\mathrm{Aa} 2$ & - & $\mathrm{Bi}$ & $\mathrm{Bi}$ & $\mathrm{Ec}$ \\
\hline
\end{tabular}

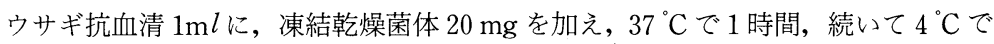
12時間吸収操作を行った。

cus sanguis ATCC 10556 は当講座保存の菌株を供試し た。Streptococcus mutans MT 8148, OMZ 175, HS-1 お よび SE-11, Streptococcus salivarius HHT, HT 3 R およ び HT $9 \mathrm{R}$ の各菌株は大嶋隆博士 (大阪大学) から, Streptococcus sanguis 34 は鳥居光男博士 (大阪大学) か ら, A. actinomycetemcomitans Y 4 および 301-b, Bacteroides melaninogenicus 7-70 および 7-92 の各菌株は加 藤慶二郎博士 (岡山大学, 岡山) から, E. corrodens $211 \mathrm{~L}$ および 301 L は山崎洋治博士 (ライオン第一応用研究所, 小田原) から, Haemophilus aphrophilus ATCC 19415 および Haemophilus influenzae ATCC 9795 の各菌株は 大阪大学微生物病研究所 (大阪) から恵与された。

上記菌株の培養条件は以下のとおりである。すなわ ち, Streptococcus 属および Actinomyces 属の各菌株は, Brain Heart Infusion Broth (以下 BHI と略す, Difco Laboratories, Detroit, USA) にて, $37^{\circ} \mathrm{C}$ で, 24 時閒培 養した。Actinobacillus 属の 4 菌株は, BHI で $37^{\circ} \mathrm{C}, 24$ 時間, 嫌気的条件下 (95\% $\left.\mathrm{N}_{2}, 5 \% \mathrm{CO}_{2}\right)$ にて培養した。 Eikenella 属の 5 菌株は, $2 \mathrm{mg} / \mathrm{ml}$ の硝酸カリウム（和光 純薬, 大阪) と $5 \mu \mathrm{g} / \mathrm{m} l$ のヘミン (和光純薬) を含む Triptic Soy Broth (以下 TS と略す, Difco Laboratories) で, Fusobacterium 属の 6 菌株は, $0.5 \mu \mathrm{g} / \mathrm{m} l$ の Lシステイン (和光純薬) を含む TS で, それぞれ $37^{\circ} \mathrm{C}$, 24 時間, 嫌気的に培養した。Bacteroides 属の各菌株は, $5 \mu \mathrm{g} / \mathrm{m} l$ のヘミン (和光純薬), $0.5 \mu \mathrm{g} / \mathrm{m} l$ のメナジオン (和光純薬) を含む BHI (Difco Laboratories) で, $37^{\circ} \mathrm{C}$, 48 時間, 嫌気的に培養した。Haemophilus 属の各菌株 は, $5 \mu \mathrm{g} / \mathrm{m} l$ のヘミン (和光純薬) を含む BHI (Difco Laboratories) で, $37^{\circ} \mathrm{C}, 24$ 時間培養した。

それぞれの培養終了後, $7,000 \times \mathrm{g}$ で 10 分間遠心して 集菌し, 得られた菌体を pH 7.2 の $10 \mathrm{mM}$ リン酸塩緩 衝生理食塩水 (以下 PBS と略す) にて 3 回洗浄した後, 以下の実験に用いた。

\section{5. ウサギ抗血清の調製}

ウサギ抗血清の作製は木村の記載 ${ }^{29)}$ 参考にして行っ た。すなわち，歯周炎と関連が深いと目されている， $A$. viscosus (以下 Av と略す) から ATCC 19246 株を, $A$. actinomycetemcomitans (以下 Aa と略す) から ATCC
29522 (Aa 2) 株および ATCC 29523 (Aa 3) 株を, E. corrodens (以下 Ec と略す) から 1073 株を, F. nucleatum (以下 Fn と略す) から 1436 株を, B. gingivalis (以下 $\mathrm{Bg}$ と略す) から 381 株を, B. intermedius (以下 $\mathrm{Bi}$ と略す）から ATCC 33563 株を選択し（以下これ らの細菌を特定細菌と称す), それぞれの凍結 乾燥菌体 (6 mg) を滅菌生理食塩水 (大塚製薬, 東京) $3 \mathrm{~m} l$ に浮 遊させ，等量のFreund の完全アジュバンド（Difco Laboratories）と十分に混和した。得られたエマルジョ ンの計 $2 \mathrm{~m} l$, 体重約 $3 \mathrm{~kg}$ のオスのニュージーラン ドラビット（静岡県実験動物農業共同組合, 静岡) の背 部皮下に, $0.4 \mathrm{~m} l$ ずつ 5 カ所に分けて注射した。2 週間 後, 同様にして皮下に追加免疫を行い, さらに 2 週間後, ホルマリン処理した菌体を $1 \mathrm{mg} / \mathrm{ml}$ の濃度に滅菌生理 食塩水に浮遊させた菌液 $3 \mathrm{~m} l$ を静脈内にブースター注 射した。初回免疫から 5 週間後に採血し，血清を分離し てチメロサール (Sigma Chemical Co.) を 0.01\%の濃 度になるように添加した。

\section{6. 抗血清の吸収}

得られた抗血清を用いて間接螢光抗体法によりそれぞ れの特定細菌を染色した結果, 抗 Aa 3 血清により Aa 2 が強く光った他, 表 1 に示した組み合わせでごくわずか な螢光を発したので, この交差性を示した菌株により抗 血清を吸収した。吸収処理は Zambon ら ${ }^{30)}$ の記載をも とにして行った。すなわち, 凍結乾燥菌体 $20 \mathrm{mg}$ をウ サギ抗血清 $1 \mathrm{~m} l$ に加え, $37^{\circ} \mathrm{C}$ で 1 時閒振盪し, さらに $4^{\circ} \mathrm{C}$ にて 12 時間静置した。そして, $7,000 \times \mathrm{g}$ の遠心に より得られた上清を, 各特定細菌に対する抗血清として, 以下の実験に用いた。

\section{7. 間接螢光抗体法による特定細菌の検出系}

スライドグラス上に, 被験部位から採取した歯肉縁下 プラーク浮遊液を $10 \mu l$ 滴下し, 自然乾燥後, 火焰固定 した。そして, 1\%ウシ血清アルブミン (以下 BSA と略 す, Sigma Chemical Co.) および 0.02\% アジ化ナトリウ ム (和光純薬) を加えた PBS によって, 500 倍に希釈し たそれぞれの特定細菌に対するウサギ抗血清を 1 次抗体 として滴下し, 湿箱中にて $37^{\circ} \mathrm{C}$ で 1 時間インキュベー トした後, PBS にて 3 回洗浄した。つぎに, $1 \%$ BSA と 
$0.02 \%$ アジ化ナトリウムを添加した PBS で 100 倍に希 釈したフルオレッセインイソチオシアネート標識ヤギ抗 ウサギ IgG (Cappel, Malvern, PA) を2次抗体として 滴下し, 1 次抗体の場合と同じ条件下でインキュベート した後, 再度 PBS で 3 回洗浄し, $0.1 \%$ パラフェニレン ジアミン(和光純薬) および $10 \%$ トリス塩酸緩衝液( 0.1 $\mathrm{M}, \mathrm{pH}$ 7.4）を加えたグリセロールで封入した。このよ らにして得られた標本を䖝光顕微鏡 (MICROPHOT$\mathrm{FX}$, 日本光学工業 $\mathrm{KK}$, 東京) を使用して観察し, 螢光 物質による細菌の輪郭の明瞭性および形態を判断基準と して, 螢光陽性細菌数を測定した。また, 同一視野を位 相差顕微鏡で観察することによって総菌数を求め, これ に対する螢光陽性細菌数の比率を算出して, 特定細菌の 検出率とした。

\section{ELISA 法による血清 $\mathbf{I g} \mathrm{G}$ 抗体価の測定}

各特定細菌の凍結乾燥菌体を, $0.1 \mathrm{M}$ 炭酸緩衝液 $(\mathrm{pH}$ 9.6)に $100 \mu \mathrm{g} / \mathrm{m} l$ の濃度に浮遊させ, 96 穴 ELISA 用マ ルチプレート（住友ベークライト，東京）の各ウェルに $100 \mu l$ ずつ加え, $4^{\circ} \mathrm{C}$ で一晚放置して抗原を吸着させた。 そして, 0.05\% Tween-20 (和光純薬) 添加 PBS (以下 PBST と略す) にて 3 回洗浄後, PBST で 500 倍に希勫 した被験者血清を $100 \mu l /$ well 加え, $37^{\circ} \mathrm{C}$ で 1 時間イン キュベートした後, PBST で 3 回洗浄した。ついで, PBST にて 6,000 倍に希釈したアルカリホスファターゼ 標識ヤギ抗ヒト IgG (TAGO, Inc., Burilngame, Ca., USA)を $100 \mu \mathrm{l} / \mathrm{well}$ ずつ加え, $37^{\circ} \mathrm{C}$ で 1 時間インキュ ベートした。3 回洗浄後, $10 \%$ ジェタノールアミン（和 光純薬）緩衝液にパラニトロフェニルリン酸 2 ナトリウ ム (和光純薬)を $1 \mathrm{mg} / \mathrm{m} l$ の割合で溶解した発色試薬を $100 \mu \mathrm{l} / \mathrm{well}$ ずつ加えた。そして, 室温にて 30 分間イン キュベートして発色させた後に, $3 \mathrm{~N} \mathrm{NaOH}$ を各ウェル に $50 \mu l$ ずつ加えて反応を停止させた。そして各ウェル の $405 \mathrm{~nm}$ における吸光度をコロナマイクロプレート光 度計（MTP-32, コロナ電気株式会社, 茨城) を用いて 測定した。

ELISA UNIT は以下の方法で求めた。すなわち, 予 備実験にて比較的高い抗体価を示した血清を, 標準血清 として各特定細菌ごとに選択し，それぞれ $2^{5} \sim 2^{15}$ ま 段階希釈して吸光度を測定した。吸光度を縦軸, 希釈倍 率を横軸にとって得られた曲線を, 4 変数 logistic 曲線 を用いて回帰し，標準曲線を作製した。そして，標準血 清を 512 倍に希勫したときの ELISA UNITを 100 とし て, 各被験血清の相対的抗体価を算出した。

\section{9. 統計学的分析}

初診時と初期治療後における $\mathrm{PD}$, それぞれの特定細 菌の検出率および血清抗体価の比較は, $\mathrm{t}$ 検定を用いて 行い, P 1Iおよび GI の比較は Wilcoxon の検定にて比 較した。BP (+) の部位数および特定細菌の検出部位数 は, $\chi^{2}$ 検定を用いて比較した。

被験部位を臨床所見により 2 群に分類し, それぞれの 特定細菌検出率を $\mathrm{t}$ 検定により比較した。また, 患者群 と健常者群の血清抗体価も $\mathrm{t}$ 検定により比較した。

\section{結果}

\section{1. 間接螢光抗体法による特定細菌検出系の特異性}

今回調製したそれぞれの特定細菌に対する抗血清と種 々の口腔内細菌との反応性を間接螢光抗体法により検討 した結果を表 2 に示した。抗 Av 血清により A. naeslundii ATCC 12104 が，また抗 Ec 血清により B. ureolyticus 32 が螢光を発した他は, 異なる菌種間で著明な交 差反応は見られず, 分類学的に Aa が属するであろうと いう報告 ${ }^{31}$,32) がある Haemophilus 属の 2 菌種も，抗 $\mathrm{Aa}$ 血清により，ごく微弱な螢光を発した程度であった。し たがって, この系が有する特異性は比較的高いことが示 された。

同一菌種でも異なった菌株の間では各抗血清に対して どのような反応性を示すかを検討した結果, 抗 Ec 血清, 抗 Bg 血清および抗 Bi 血清は調べた各菌株に対して強 い反応性を示した (表 2)。また, 抗 Aa 2 血清は, 免疫 原である ATCC 29522 株と同じ血清型 b に層する Y 4 株と強く反応し, 逆に, 抗 Aa 3 血清と Y 4 株上の反応 性は低いものであった。抗 $\mathrm{Av}$ 血清はヒト由来の T $14 \mathrm{~V}$ 株とは強く反応したが，ラット由来である $\mathrm{Av}$ の $\mathrm{Ny} 1$ 株とは, 低い反応性しか示さなかった。以上の抗血清は 同じ菌種間に強い交差性を示したが，抗 Fn 血清は抗血 清を作製した菌株以外の 5 株中 4 株と微陽性反応を示し たにすぎず，調製した抗 Fn 血清による Fn の検出率は 培養法による場合よりも低くなることが予測された。

\section{2. 被験部位における初期治療前後の臨床所見}

初期治療を行うことによって, P 1 I, GI, PD は初診時 よりも有意に低下した (表 3 )。また, 初診時のプロービ ング時に出血がみられた部位は, 初期治療後に有意にそ の数が減少し, 全体として改善の傾向がみられた（表 3)。なお, BLS に初期治療が与える影響はわずかである と判断し, 初期治療後の骨吸収率は測定しなかった。 
表 2 特定細菌検出系による種々の口腔内細菌の反応性

\begin{tabular}{|c|c|c|c|c|c|c|c|}
\hline \multirow[b]{2}{*}{ 菌 名 } & \multicolumn{7}{|c|}{ 抗 血 清 } \\
\hline & 抗 Av & 抗 Aa2 & 抗 Aa3 & 抗 Ec & 抗 Fn & 抗 $\mathrm{Bg}$ & 抗 $\mathrm{Bi}$ \\
\hline Streptococcus mutans MT 8148 & - & - & - & - & - & - & - \\
\hline OMZ 175 & - & - & - & - & - & - & - \\
\hline HS-1 & - & - & - & - & - & - & - \\
\hline SE-11 & - & - & - & - & - & - & - \\
\hline Streptococcus sanguis ATCC 10556 & - & - & - & - & - & - & - \\
\hline 34 & - & - & - & - & - & - & - \\
\hline Streptococcus salivarius HHT & - & - & - & - & - & - & - \\
\hline HT 3 R & - & - & - & - & - & - & - \\
\hline HT 9 R & - & - & - & - & - & - & - \\
\hline Actinomyces viscosus ATCC 19246 & ++ & - & - & - & - & - & - \\
\hline T $14 \mathrm{~V}$ & ++ & - & - & - & - & - & - \\
\hline Ny 1 & \pm & - & - & - & - & - & - \\
\hline Actinomyces naeslundii ATCC 12104 & + & - & - & - & - & - & - \\
\hline Actinobacillus & & & & & & & \\
\hline actinomycetemcomitans ATCC 29522 & - & ++ & - & - & - & - & - \\
\hline ATCC 29523 & - & - & ++ & - & - & - & - \\
\hline Y 4 & - & ++ & \pm & - & - & - & - \\
\hline $301-b$ & - & \pm & - & - & - & - & - \\
\hline Haemophilus aphrophilus ATCC 19415 & - & \pm & - & - & - & - & - \\
\hline Haemophilus influenzae ATCC 9795 & - & \pm & \pm & - & - & - & - \\
\hline Eikenella corrodens 1073 & - & - & - & ++ & - & - & - \\
\hline 1080 & - & - & - & + & - & - & - \\
\hline 375 & - & - & - & + & - & - & - \\
\hline $211 \mathrm{~L}$ & - & - & - & ++ & - & - & - \\
\hline $301 \mathrm{~L}$ & - & - & - & ++ & - & - & \pm \\
\hline Fusobacterium nucleatum 1436 & - & - & - & - & ++ & - & - \\
\hline 325 & - & - & - & - & + & - & - \\
\hline 364 & - & - & - & - & \pm & - & - \\
\hline 398 & - & - & - & - & \pm & - & - \\
\hline 1439 & - & - & - & - & \pm & - & - \\
\hline 1440 & - & - & - & - & \pm & - & - \\
\hline Bacteroides gingivalis 381 & - & - & - & - & - & ++ & - \\
\hline ATCC 33277 & - & - & - & - & - & + & - \\
\hline $\mathrm{H}$ & - & - & - & - & - & ++ & \pm \\
\hline 21 & - & - & - & - & - & ++ & \pm \\
\hline Bacteroides intermedius ATCC 33563 & - & - & - & - & - & - & ++ \\
\hline ATCC 25611 & - & - & - & - & - & - & ++ \\
\hline Bacteroides gracilis 21 & - & - & - & - & - & - & - \\
\hline Bacteroides ureolyticus 32 & - & - & - & + & - & - & - \\
\hline Bacteroides melaninogenicus 7-70 & - & - & - & - & - & - & \pm \\
\hline 7-92 & - & - & - & - & - & - & \pm \\
\hline
\end{tabular}

一：蛍光がまったく観察されない

土 : 微弱な蛍光を発するが, 菌の輪郭が不明瞭

+ : 菌の形態が明瞭に把握できる程度の蛍光を発する

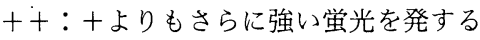




\section{3. 特定細菌の検出率および検出部位率}

初診時ならびに初期治療後のそれぞれの特定細菌の検 出率を表 4 に, 検出部位率を表 5 に示した。初診時の検 出率は，最高が $\mathrm{Bg}$ の $3.50 \%$ であり，いずれも低い值 であったが, 検出部位率では被験部位の約 $80 \%$ から Av, $\mathrm{Bg} ＼textrm{B i}$ が検出された。そして初期治療を行うことによ って，Bg および Bi の検出率が有意に低下したが， Av は逆に上昇する傾向がみられた。また, 検出部位率は $\mathrm{Av}$ 以外の菌種において減少する傾向がみられ, 特に $\mathrm{Fn}, \mathrm{Bg}, \mathrm{Bi}$ の 3 菌種において有意に低下した。Aa 2 は 本研究の被験者からは，まったく検出されなかった。

\section{4. 特定細菌に対する血清中の IgG 抗体価}

被験者のうち初期治療が終了した 32 名の患者群と 32 名の健常者群における, それぞれの特定細菌に対する血。

表 3 被験部位の臨床所見

\begin{tabular}{|c|c|c|}
\hline & 初診時 & 初期治療後 \\
\hline P 1 I & $1.1 \pm 0.1^{\mathrm{a}}$ & $0.6 \pm 0.1^{*}$ \\
\hline GI & $1.3 \pm 0.1$ & $0.7 \pm 0.1^{*}$ \\
\hline PD & $6.6 \pm 0.2$ & $4.7 \pm 0.2^{* *}$ \\
\hline $\mathrm{BP}$ & $81 / 97^{\mathrm{b}}$ & $33 / 97^{* * *}$ \\
\hline BLS & $33.8 \pm 1.9$ & N. D. \\
\hline \multicolumn{3}{|c|}{ a : 平均值土標準誤差 } \\
\hline \multicolumn{3}{|c|}{ b : 出血部位/被験部位 } \\
\hline \multicolumn{3}{|c|}{ N. D. : 測定せず } \\
\hline \multicolumn{3}{|c|}{ * : 初期治療後有意に減少 } \\
\hline \multicolumn{3}{|c|}{ ** : 初期治療後有意に減少 } \\
\hline \multicolumn{2}{|c|}{ ***：初期治療後有意に減少 } & \\
\hline
\end{tabular}

清 IgG 抗体価を表 6 に示す。初診時における患者群の 抗 $\mathrm{Bg}$ 抗体価は健常者よりも有意に高く, 被験者全員が 健常者の平均值を標準偏差の 2 倍以上越える高い值を示 した。

一方，Av に対する患者群の抗体価は健常者よりも有意 に低い值であった。患者の抗体価は，抗 Av 抗体価を除 いて，初期治療によって減少する傾向にあり，なかでも

表 4 特定細菌の検出率（\%）

\begin{tabular}{|c|c|c|}
\hline & 初診時 & 初期治療後 \\
\hline $\mathrm{Av}$ & $1.32 \pm 0.16^{\mathrm{a}}$ & $2.13 \pm 0.31$ \\
\hline $\mathrm{Aa} 2$ & 0 & 0 \\
\hline Aa 3 & $0.02 \pm 0.01$ & $0.02 \pm 0.01$ \\
\hline Ec & $0.04 \pm 0.01$ & $0.03 \pm 0.01$ \\
\hline Fn & $0.24 \pm 0.05$ & $0.22 \pm 0.09$ \\
\hline $\mathrm{Bg}$ & $3.50 \pm 0.36$ & $0.66 \pm 0.11^{*}$ \\
\hline $\mathrm{Bi}$ & $1.26 \pm 0.17$ & $0.63 \pm 0.16^{*}$ \\
\hline \multicolumn{3}{|c|}{ 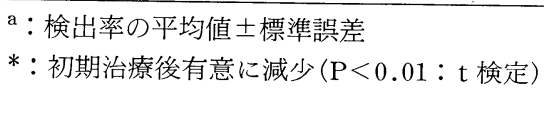 } \\
\hline \multicolumn{3}{|c|}{ 表 5 特定細菌の検出部位率 } \\
\hline & 初診時 & 初期治療後 \\
\hline Av & $81 / 97^{\mathrm{a}}$ & $80 / 97$ \\
\hline $\mathrm{Aa} 2$ & $0 / 97$ & $0 / 97$ \\
\hline Aa 3 & $7 / 97$ & $4 / 97$ \\
\hline $\mathrm{Ec}$ & $12 / 97$ & $5 / 97$ \\
\hline Fn & $36 / 97$ & $12 / 97^{*}$ \\
\hline $\mathrm{Bg}$ & $84 / 97$ & $48 / 97^{*}$ \\
\hline $\mathrm{Bi}$ & $72 / 96$ & $35 / 96^{*}$ \\
\hline
\end{tabular}

表 6 特定細菌に対する血清中 IgG 抗体価 (E.U.)

\begin{tabular}{|c|c|c|c|}
\hline & \multirow[t]{2}{*}{ 健常者群 (n=32) } & \multicolumn{2}{|c|}{ 患者群 (n=32) } \\
\hline & & 初診時 & 初期治療後 \\
\hline $\mathrm{Av}$ & $194.9 \pm 41.9^{\mathrm{a}}$ & $98.9 \pm 13.6^{*}$ & $110.5 \pm 132.1$ \\
\hline $\mathrm{Aa} 2$ & $340.0 \pm 61.7$ & $431.4 \pm 88.7$ & $353.8 \pm 135.1$ \\
\hline $\mathrm{Aa} 3$ & $176.3 \pm 29.0$ & $341.5 \pm 58.5$ & $265.5 \pm 56.4^{* *}$ \\
\hline Ec & $163.7 \pm 31.1$ & $160.7 \pm 20.0$ & $148.2 \pm 17.8$ \\
\hline Fn & $89.2 \pm 9.7$ & $76.3 \pm 10.9$ & $75.8 \pm 9.7$ \\
\hline $\mathrm{Bg}$ & $26.7 \pm 4.8$ & $994.6 \pm 166.8^{*}$ & $487.5 \pm 155.2^{*, * *}$ \\
\hline $\mathrm{Bi}$ & $95.6 \pm 14.8$ & $93.5 \pm 12.1$ & $71.8 \pm 8.9^{* *}$ \\
\hline
\end{tabular}

a : 抗体価の平均值士標準誤差

$*$ : 健常者の抗体価に対し有意差あり $(\mathrm{P}<0.01: \mathrm{t}$ 検定 $)$

** : 初診時よりも初期治療後に有意に減少 $(\mathrm{P}<0.05: \mathrm{t}$ 検定 $)$ 
表 7 初診時のプラーク指数と特定細菌 検出率 (\%)

\begin{tabular}{lcc}
\hline & $\mathrm{P} 1 \mathrm{I}=0(\mathrm{n}=26)$ & $\mathrm{P} 1 \mathrm{I}=2$ or $3(\mathrm{n}=45)$ \\
\cline { 2 - 3 } $\mathrm{Av}$ & $0.79 \pm 0.20^{\mathrm{a}}$ & \\
$\mathrm{Aa} 2$ & 0 & $1.53 \pm 0.29$ \\
$\mathrm{Aa} 3$ & $0.02 \pm 0.01$ & $0.03 \pm 0.02$ \\
$\mathrm{Ec}$ & $0.08 \pm 0.06$ & $0.03 \pm 0.01$ \\
$\mathrm{Fn}$ & $0.30 \pm 0.10$ & $0.32 \pm 0.10$ \\
$\mathrm{Bg}$ & $3.15 \pm 0.82$ & $3.03 \pm 0.46$ \\
$\mathrm{Bi}$ & $1.50 \pm 0.54$ & $1.37 \pm 0.25$ \\
\hline
\end{tabular}

a : 検出率の平均值士標準誤差

表 8 初診時の歯肉炎指数と特定細菌 検出率（\%)

\begin{tabular}{lccc}
\hline & $\mathrm{GI}=0(\mathrm{n}=14)$ & & $\mathrm{GI}=2$ or $3(\mathrm{n}=49)$ \\
\cline { 2 - 2 } $\mathrm{Av}$ & $0.97 \pm 0.25^{\mathrm{a}}$ & & $0.99 \pm 0.55$ \\
$\mathrm{Aa} 2$ & 0 & & 0 \\
$\mathrm{Aa} 3$ & $0.01 \pm 0.01$ & & $0.03 \pm 0.02$ \\
$\mathrm{Ec}$ & $0.08 \pm 0.05$ & & $0.03 \pm 0.01$ \\
$\mathrm{Fn}$ & $0.16 \pm 0.07$ & & $0.15 \pm 0.07$ \\
$\mathrm{Bg}$ & $1.18 \pm 0.65$ & & $3.57 \pm 0.59^{*}$ \\
$\mathrm{Bi}$ & $0.82 \pm 0.39$ & & $1.41 \pm 0.36$ \\
\hline
\end{tabular}

$\mathrm{a}:$ 検出率の平均値士標準誤差

* : $\mathrm{GI}=0$ の群に対し有意差あり $(\mathrm{P}<0.05 ： \mathrm{t}$ 検定 $)$

表 9 初診時におけるプロービング時の出血の 有無と特定細菌検出率（\%）

\begin{tabular}{lccc}
\hline & $\mathrm{BP}(-)(\mathrm{n}=38)$ & & $\mathrm{BP}(+)(\mathrm{n}=110)$ \\
\cline { 2 - 2 } $\mathrm{Av}$ & $1.31 \pm 0.20^{\mathrm{a}}$ & & $1.43 \pm 0.20$ \\
$\mathrm{Aa} 2$ & 0 & & 0 \\
$\mathrm{Aa} 3$ & $0.03 \pm 0.01$ & & $0.02 \pm 0.01$ \\
$\mathrm{Ec}$ & $0.09 \pm 0.03$ & & $0.04 \pm 0.02$ \\
$\mathrm{Fn}$ & $0.11 \pm 0.05$ & & $0.28 \pm 0.05$ \\
$\mathrm{Bg}$ & $1.07 \pm 0.35$ & & $3.20 \pm 0.35^{*}$ \\
$\mathrm{Bi}$ & $1.00 \pm 0.28$ & & $1.21 \pm 0.18$ \\
\hline
\end{tabular}

$\mathrm{a}:$ 検出率の平均值士標準誤差

* : BP (一)の群に対し有意差あり $(\mathrm{P}<0.01 ： \mathrm{t}$ 検定 $)$

$\mathrm{Aa} 3, \mathrm{Bg}, \mathrm{Bi}$ に対する抗体価は有意な低下がみられた。 ただし, 抗 $\mathrm{Bg}$ 抗体価は初期治療の後も, 健常者よりも なお有意に高い值を示していた。

\section{5. 初診時臨床所見と特定細菌検出率の関連性}

52 名の患者から選択した 148 被験部位から, 初診時に おける臨床所見によって歯肉縁上プラーク量が多い群と 少ない群, また炎症の程度が高い群と低い群を選出し, それぞれの特定細菌検出率を比較検討した。
表 10 初診時のポケット深さと特定細菌 検出率（\%)

\begin{tabular}{lccc}
\hline & $\mathrm{PD}=2$ or $3 \mathrm{~mm}(\mathrm{n}=20)$ & $\mathrm{PD} \geqq 7 \mathrm{~mm}(\mathrm{n}=49)$ \\
\cline { 2 - 2 } $\mathrm{Av}$ & $1.97 \pm 0.37^{\mathrm{a}}$ & & $1.28 \pm 0.26$ \\
$\mathrm{Aa} 2$ & 0 & & $0.02 \pm 0.02$ \\
$\mathrm{Aa} 3$ & $0.01 \pm 0.01$ & & $0.03 \pm 0.01$ \\
$\mathrm{Ec}$ & $0.11 \pm 0.06$ & & $0.22 \pm 0.06$ \\
$\mathrm{Fn}$ & $0.11 \pm 0.04$ & & 0.26 \\
$\mathrm{Bg}$ & $0.30 \pm 0.24$ & & $3.73 \pm 0.49^{*}$ \\
$\mathrm{Bi}$ & $0.63 \pm 0.30$ & & $1.39 \pm 0.25$
\end{tabular}

$\mathrm{a}:$ 検出率の平均値士標準誤差

*: $\mathrm{PD}=2$ or $3 \mathrm{~mm}$ の群に対し有意差あり $(\mathrm{P}<0.01: \mathrm{t}$ 検定 $)$

表 11 初診時の骨吸収率と特定細菌検出率（\%)

\begin{tabular}{lccc} 
& $\mathrm{BLS} \leqq 20 \%(\mathrm{n}=44)$ & & $\mathrm{BLS} \geqq 50 \%(\mathrm{n}=32)$ \\
\cline { 2 - 2 } $\mathrm{Av}$ & $1.38 \pm 0.21^{\mathrm{a}}$ & & $1.22 \pm 0.41$ \\
$\mathrm{Aa} 2$ & 0 & & 0 \\
$\mathrm{Aa} 3$ & $0.01 \pm 0.01$ & & $0.03 \pm 0.02$ \\
$\mathrm{Ec}$ & $0.05 \pm 0.03$ & & $0.04 \pm 0.02$ \\
$\mathrm{Fn}$ & $0.25 \pm 0.08$ & & $0.26 \pm 0.09$ \\
$\mathrm{Bg}$ & $2.37 \pm 0.63$ & & $3.52 \pm 0.69$ \\
$\mathrm{Bi}$ & $1.76 \pm 0.44$ & & $1.14 \pm 0.25$ \\
\hline
\end{tabular}

$\mathrm{a}$ : 検出率の平均值士標準誤差

P 1 I が 0 の群と, 2 または 3 の群における細菌検出率 は，いずれの菌種についても両群間に有意差は認められ なかった（表 7)。

$\mathrm{GI}$ が 0 の群と 2 または 3 の群, $\mathrm{BP}$ が (十) の群と (一)の群, $\mathrm{PD}$ が $2 \mathrm{~mm}$ または $3 \mathrm{~mm}$ と浅い群と $7 \mathrm{~mm}$ 以上の深い群に分類して, 細菌検出率を比較した（表 8 , 9，10）。いずれの場合においても，臨床的に歯肉の炎症 程度が強いあるいは歯周組織の破壊程度が大きいと判断 される部位では，炎症が観察されないあるいは破壊の程 度が小さい部位よりも，Bg が高い比率で検出された。 $\mathrm{Bg}$ 以外の菌種の検出率に関しては，両群間に有意差は みられなかった。

骨吸収率が $20 \%$ 以下の群と $50 \%$ 以上の群における細 菌検出率を比較すると, 骨吸収率が大きい群では $\mathrm{Bg}$ の 検出率が高い傾向にあったが, 統計学的な有意差は認め られなかった (表 11)。Bg 以外の菌種の検出率も, 両群 間で有意差はみられなかった。

\section{6. 初期治療による臨床指数の変動と特定細菌検出率 之の関係}

初期治療が終了した 32 名の患者の 97 部位から, 初期 
表 12 プラーク指数の変動と初診時の特定細菌 検出率 (\%)

\begin{tabular}{lclc}
\hline & P1I 改善群 ${ }^{\mathrm{a}}(\mathrm{n}=10)$ & & P1I 非改善群 ${ }^{\mathrm{b}}(\mathrm{n}=14)$ \\
\cline { 2 - 2 } $\mathrm{Av}$ & $2.14 \pm 0.67^{\mathrm{c}}$ & & $1.75 \pm 0.71$ \\
$\mathrm{Aa} 2$ & 0 & 0 \\
$\mathrm{Aa} 3$ & $0.10 \pm 0.08$ & & $0.01 \pm 0.01$ \\
$\mathrm{Ec}$ & $0.08 \pm 0.06$ & & $0.02 \pm 0.01$ \\
$\mathrm{Fn}$ & $0.25 \pm 0.13$ & & $0.47 \pm 0.21$ \\
$\mathrm{Bg}$ & $3.41 \pm 1.10$ & & $1.99 \pm 0.95$ \\
$\mathrm{Bi}$ & $0.96 \pm 0.30$ & & $1.74 \pm 0.45$ \\
\hline
\end{tabular}

a : 初期治療の前後で P 1 I が 2 以上減少した部位

b : 初期治療の前後で P1I が変化しなかった あるいは增加した部位

$\mathrm{c}$ : 検出率の平均值士標準誤差

表 13 歯肉炎指数の変動と初診時の特定細菌 検出率 (\%)

\begin{tabular}{lccc}
\hline & GI 改善群 ${ }^{\mathrm{a}}(\mathrm{n}=49)$ & & GI 非改善群 ${ }^{\mathrm{b}}(\mathrm{n}=12)$ \\
\cline { 2 - 2 } $\mathrm{Av}$ & $1.66 \pm 0.27^{\mathrm{c}}$ & & $0.94 \pm 0.28$ \\
$\mathrm{Aa} 2$ & 0 & & 0 \\
$\mathrm{Aa} 3$ & $0.03 \pm 0.02$ & & $0.02 \pm 0.02$ \\
$\mathrm{Ec}$ & $0.09 \pm 0.04$ & & $0.01 \pm 0.01$ \\
$\mathrm{Fn}$ & $0.30 \pm 0.08$ & & $0.09 \pm 0.06$ \\
$\mathrm{Bg}$ & $4.80 \pm 0.79$ & & $2.55 \pm 0.70$ \\
$\mathrm{Bi}$ & $1.49 \pm 0.37$ & & $1.38 \pm 0.51$ \\
\hline
\end{tabular}

a : 初期治療の前後で GI が減少した部位

b : 初期治療の前後で GI が変化しなかった あるいは増加した部位

$\mathrm{c}:$ 検出率の平均值士標準誤差

治療により臨床所見に改善が認められた群と認められな かった群を選出し, 両群における細菌検出率の異同を検 討した。分類方法を一括して述べると, P 1 I が 2 以上減 少した P 1I 改善群と変化なしまたは増加した P 1I 非 改善群 (表 12 および 16), GI が減少した GI 改善群と変 化なしまたは増加した GI 非改善群（表 13 および 17),

初診時の BP が（十）であったが初期治療後に BP が （一）となった BP 改善群と, 初診時および初期治療後と も BP が $(+)$ であった部位と初診時には BP が $(-)$ であったが初期治療後の BP は（十）であった部位を合 わせた BP 非改善群（表 14 および 18），PD が $3 \mathrm{~mm}$ 以 上減少した $\mathrm{PD}$ 改善群と変化なしまたは増加した $\mathrm{PD}$ 非 改善群（表 15 および 19）である。

表 12〜15 は, 両群間で初診時の細菌検出率に違いが みられるか否かを検討したものであるが，いずれの場合 にも検出率に有意差は無く, 初期治療に対する歯周組織
表 14 プロービング時の出血の変動と初診時の 特定細菌検出率（\%)

\begin{tabular}{lccc}
\hline & BP 改善群 ${ }^{\mathrm{a}}(\mathrm{n}=50)$ & & BP 非改善群 ${ }^{\mathrm{b}}(\mathrm{n}=33)$ \\
\cline { 2 - 2 } $\mathrm{Av}$ & $1.74 \pm 0.32^{\mathrm{c}}$ & & $1.21 \pm 0.38$ \\
$\mathrm{Aa} 2$ & 0 & 0 \\
$\mathrm{Aa} 3$ & $0.01 \pm 0.01$ & & $0.01 \pm 0.01$ \\
$\mathrm{Ec}$ & $0.05 \pm 0.03$ & & $0.03 \pm 0.02$ \\
$\mathrm{Fn}$ & $0.38 \pm 0.08$ & & $0.31 \pm 0.13$ \\
$\mathrm{Bg}$ & $3.49 \pm 0.58$ & & $3.93 \pm 0.68$ \\
$\mathrm{Bi}$ & $1.35 \pm 0.32$ & & $1.04 \pm 0.22$ \\
\hline
\end{tabular}

a : 初診時 BP $(+)$ が初期治療後 BP (-) に なった部位

$\mathrm{b}$ : 初診時 $\mathrm{BP}(+)$ あるいは BP (一) が初期治療後 $\mathrm{BP}(+)$ になった部位

$c$ : 検出率の平均值士標準誤差

表 15 ポケット梁さの変動と初診時の特定細菌 検出率 (\%)

\begin{tabular}{|c|c|c|}
\hline & PD 改善群 ${ }^{a}(n=18)$ & $\mathrm{PD}$ 非改善群 ${ }^{\mathrm{b}}(\mathrm{n}=17)$ \\
\hline Av & $1.87 \pm 0.62^{\mathrm{c}}$ & $1.23 \pm 0.59$ \\
\hline $\mathrm{Aa} 2$ & 0 & 0 \\
\hline $\mathrm{Aa} 3$ & $0.04 \pm 0.42$ & $0.01 \pm 0.01$ \\
\hline Ec & $0.01 \pm 0.01$ & 0 \\
\hline $\mathrm{Fn}$ & $0.20 \pm 0.08$ & $0.41 \pm 0.16$ \\
\hline $\mathrm{Bg}$ & $4.14 \pm 0.86$ & $4.90 \pm 1.21$ \\
\hline $\mathrm{Bi}$ & $0.72 \pm 0.17$ & $1.78 \pm 0.71$ \\
\hline
\end{tabular}

a : 初期治療の前後で PD が $3 \mathrm{~mm}$ 以上減少した部位

b : 初期治療の前後で PD が 変化しなかったあるいは 増加した部位

$c$ : 検出率の平均値士標準誤差

表 16 プラーク指数の変動と初期治療後の特定 細菌検出率 (\%)

\begin{tabular}{|c|c|c|}
\hline & P1I 改善群 ${ }^{\mathrm{a}}(\mathrm{n}=10)$ & $\mathrm{P} 1 \mathrm{I}$ 非改善群 ${ }^{\mathrm{b}}(\mathrm{n}=14)$ \\
\hline Av & $4.16 \pm 2.16^{c}$ & $2.59 \pm 0.46$ \\
\hline $\mathrm{Aa} 2$ & 0 & 0 \\
\hline $\mathrm{Aa} 3$ & 0 & $0.03 \pm 0.03$ \\
\hline Ec & 0 & $0.04 \pm 0.04$ \\
\hline Fn & 0 & $0.39 \pm 0.27$ \\
\hline $\mathrm{Bg}$ & $0.60 \pm 0.40$ & $0.56 \pm 0.23$ \\
\hline $\mathrm{Bi}$ & $0.23 \pm 0.17$ & $1.01 \pm 0.38$ \\
\hline
\end{tabular}

a : 初期治療の前後で P1I が 2 以上減少した部位

b : 初期治療の前後で P1I が変化しなかった

あるいは増加した部位

$c$ : 検出率の平均値士標準誤差 
表 17 歯肉炎指数の変動と初期治療後の特定細菌 検出率 (\%)

\begin{tabular}{lccc}
\hline & GI 改善群 ${ }^{\mathrm{a}}(\mathrm{n}=49)$ & & GI 非改善群 ${ }^{\mathrm{h}}(\mathrm{n}=12)$ \\
\cline { 2 - 2 } $\mathrm{Av}$ & $2.63 \pm 0.55^{\mathrm{c}}$ & & $1.19 \pm 0.50$ \\
$\mathrm{Aa} 2$ & 0 & & 0 \\
$\mathrm{Aa} 3$ & $0.01 \pm 0.01$ & & $0.03 \pm 0.03$ \\
$\mathrm{Ec}$ & $0.01 \pm 0.01$ & & $0.06 \pm 0.04$ \\
$\mathrm{Fn}$ & $0.16 \pm 0.08$ & & 0 \\
$\mathrm{Bg}$ & $0.72 \pm 0.17$ & & $0.67 \pm 0.24$ \\
$\mathrm{Bi}$ & $0.50 \pm 0.18$ & & $0.55 \pm 0.39$ \\
\hline
\end{tabular}

$\mathrm{a}$ : 初期治療の前後で GI が減少した部位

b : 初期治療の前後で GI が変化しなかった あるいは増加した部位

c : 検出率の平均値士標準誤差

表 18 プロービング時の出血の変動と初期治療後 の特定細菌検出率（\%）

\begin{tabular}{|c|c|c|}
\hline & 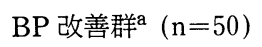 & 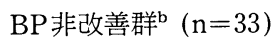 \\
\hline Av & $2.03 \pm 0.30^{c}$ & $2.12 \pm 0.54$ \\
\hline $\mathrm{Aa} 2$ & 0 & 0 \\
\hline $\mathrm{Aa} 3$ & 0 & $0.04 \pm 0.03$ \\
\hline Ec & $0.01 \pm 0.01$ & $0.04 \pm 0.03$ \\
\hline Fn & $0.20 \pm 0.15$ & $0.38 \pm 0.16$ \\
\hline $\mathrm{Bg}$ & $0.54 \pm 0.16$ & $1.04 \pm 0.20^{*}$ \\
\hline $\mathrm{Bi}$ & $0.39 \pm 0.15$ & $0.91 \pm 0.30$ \\
\hline
\end{tabular}

a : 初診時 BP $(+)$ が初期治療後 BP $($ - ) になった 部位

b : 初診時 BP $(+)$ あるいは BP (一) が初期治療後 $\mathrm{BP}(+)$ になった部位

$\mathrm{c}$ : 検出率の平均値士標準誤差

* : BP 改善群に対し有意差あり $(\mathrm{P}<0.05: \mathrm{t}$ 検定 $)$

の反応性を初診時の細菌検出率によって子測することは できなかった。

表 16〜19 は, 初期治療後の細菌検出率が両群間 で 異 なるか否かを調べたものである。P 1 I または GI の改善 度によって被験部位を 2 群に分けても, 細菌検出率に有 意差はみられなかった（表 16 および 17)。一方, BP ま たは PDの改善度により 2 群に分類した場合，それぞれ の非改善群では改善群よりも Bg が有意に多く存在して いた（表 18 および 19）。

さらに，歯周病変をより総合的に評価する目的で，被 験部位を, GI, BP, PD のうち初期治療により 2 つ以上 の臨床指数が改善した群と, 逆に 2 つ以上の指数が改善 されなかった非改善群に分けて，それぞれの細菌検出率 を比較した。初診時の細菌検出率を両群間で比較した結
表 19 ポケット深さの変動と初期治療後の特定 細菌検出率 (\%)

\begin{tabular}{|c|c|c|}
\hline & $\mathrm{PD}$ 改善群 ${ }^{\mathrm{a}}(\mathrm{n}=18)$ & $\mathrm{PD}$ 非改善群 ${ }^{\mathrm{b}}(\mathrm{n}=17)$ \\
\hline $\mathrm{Av}$ & $3.26 \pm 1.37^{\mathrm{c}}$ & $0.95 \pm 0.27$ \\
\hline $\mathrm{Aa} 2$ & 0 & 0 \\
\hline $\mathrm{Aa} 3$ & $0.02 \pm 0.02$ & 0 \\
\hline Ec & 0 & 0 \\
\hline Fn & $0.04 \pm 0.03$ & $0.07 \pm 0.07$ \\
\hline $\mathrm{Bg}$ & $0.21 \pm 0.09$ & $1.17 \pm 0.35^{*}$ \\
\hline $\mathrm{Bi}$ & $0.32 \pm 0.24$ & $0.61 \pm 0.41$ \\
\hline
\end{tabular}

$\mathrm{a}$ : 初期治療の前後で $\mathrm{PD}$ が $3 \mathrm{~mm}$ 以上減少した部位

b : 初期治療の前後で PD が変化しなかったあるいは

増加した部位

$c$ : 検出率の平均値士標準誤差

* : PD 改善群に対し有意差あり $(\mathrm{P}<0.05: \mathrm{t}$ 検定 $)$

表 20 臨床指数の変動と初診時の特定細菌 検出率 (\%)

\begin{tabular}{|c|c|c|}
\hline & 改善群 ${ }^{\mathrm{a}}(\mathrm{n}=36)$ & 非改善群b $(n=13)$ \\
\hline $\mathrm{Av}$ & $1.75 \pm 0.34^{\mathrm{c}}$ & $0.66 \pm 0.18$ \\
\hline $\mathrm{Aa} 2$ & 0 & 0 \\
\hline $\mathrm{Aa} 3$ & $0.03 \pm 0.02$ & $0.01 \pm 0.01$ \\
\hline $\mathrm{Ec}$ & $0.08 \pm 0.04$ & 0 \\
\hline Fn & $0.30 \pm 0.08$ & $0.11 \pm 0.10$ \\
\hline $\mathrm{Bg}$ & $3.79 \pm 0.71$ & $3.45 \pm 0.64$ \\
\hline $\mathrm{Bi}$ & $1.50 \pm 0.42$ & $1.06 \pm 0.40$ \\
\hline
\end{tabular}

${ }^{\mathrm{a}}$ : GI, BP, PD のうち 2 つ以上の指数が改善した部位

b : GI, BP,PDのうち 2 つ以上の指数が改善

しなかった部位

$\mathrm{c}$ : 検出率の平均值士標準誤差

表 21 臨床指数の変動と初期治療後の特定細菌 検出率 (\%)

\begin{tabular}{|c|c|c|}
\hline & 改善群 ${ }^{\mathrm{a}}(\mathrm{n}=36)$ & 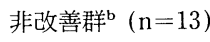 \\
\hline Av & $2.85 \pm 0.71$ & $1.52 \pm 0.59$ \\
\hline $\mathrm{Aa} 2$ & 0 & 0 \\
\hline Aa 3 & $0.01 \pm 0.01$ & $0.06 \pm 0.06$ \\
\hline Ec & 0 & $0.05 \pm 0.05$ \\
\hline Fn & $0.06 \pm 0.04$ & $0.07 \pm 0.07$ \\
\hline $\mathrm{Bg}$ & $0.33 \pm 0.12$ & $0.98 \pm 0.36^{*}$ \\
\hline $\mathrm{Bi}$ & $0.48 \pm 0.23$ & $0.48 \pm 0.36$ \\
\hline
\end{tabular}

a : GI, BP, PDのうち 2 つ以上の指数が改善した部位

b : GI, BP, PD のうち 2 つ以上の指数が改善 しなかった部位

$\mathrm{c}:$ 検出率の平均値士標準誤差

* : 改善群に対し有意差あり $(\mathrm{P}<0.05: \mathrm{t}$ 検定 $)$ 
表 22 被験部位の改善と初診時の血清中 IgG 抗体価 (E.U.)

\begin{tabular}{|c|c|c|}
\hline & 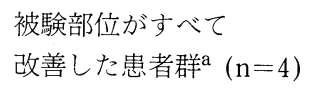 & $\begin{array}{l}\text { 非改善部位を有する } \\
\text { 患者群 }{ }^{\mathrm{b}}(\mathrm{n}=11)\end{array}$ \\
\hline $\mathrm{Av}$ & $53.9 \pm 28.9^{c}$ & $115.6 \pm 35.6$ \\
\hline $\mathrm{Aa} 2$ & $795.6 \pm 366.5$ & $354.3 \pm 163.6$ \\
\hline $\mathrm{Aa} 3$ & $613.9 \pm 171.7$ & $863.9 \pm 470.3$ \\
\hline Ec & $162.1 \pm 33.7$ & $190.2 \pm 43.6$ \\
\hline Fn & $74.5 \pm 7.6$ & $48.9 \pm 10.5$ \\
\hline $\mathrm{Bg}$ & $1539.0 \pm 884.1$ & $1018.0 \pm 323.2$ \\
\hline $\mathrm{Bi}$ & $69.9 \pm 23.0$ & $83.9 \pm 23.1$ \\
\hline
\end{tabular}

${ }^{\mathrm{a}}$ : すべての被験部位において GI, BP, PD のうち 2 つ以上 の指数が改善した患者

${ }^{\mathrm{b}}$ : GI, BP, PD のうち 2 つ以上の指数が改善しなかった 部位を 1 つまたは 2 つ口腔内に有する患者

c : 抗体価の平均值士標準誤差

果, いずれの特定細菌についても検出率に有意差は認め られなかった（表 20)。一方，初期治療後の細菌検出率 を両群間で比較した場合, 非改善群では改善群よりも Bg の検出率が有意に高い值を示した（表 21）。

\section{7. 初期治療による被験部位の改善性と血清抗体価と の関係}

表 20 および 21 に示したように, 97 被験部位の中で, 初期治療を行っても GI, BP, PD のうち 2 つ以上の臨床 指数が改善しなかった部位は 13 部位であった。この非 改善部位の各被験者における分布を調べると，口腔内に 2 つの非改善部位を有した患者が 2 名， 1 つの非改善部 位を有した患者が 9 名であった。残り 21 名の被験 部位 は, 改善群に分類されるかまたは臨床的に著明な改善は みられないものの, 非改善群には含まれないものであっ た。これに基づいて 32 名の被験者から，口腔内に非改 善部位を有する患者 11 名とすべての被験部位が改 善し た患者 4 名を選出し，それぞれの特定細菌に対する IgG 抗体価の差を検討した（表 22 および 23）。表 22 に初診 時, 表 23 に初期治療後の IgG 抗体価を示したが，いず れの特定細菌に対する抗体価についても両群間に有意差 はみられなかった。

\section{考察}

間接螢光抗体法は, 特定細菌を特異的に検出する臨床 検査法として利用できることが示唆された（表 2)。すな わち, 本研究において異なる菌種間で, 比較的明確な交 差反応を示したのは，抗 $\mathrm{Av}$ 血清と A. naeslund ii, お
表 23 被験部位の改善と初期治療後の血清中 IgG 抗体価 (E.U.)

\begin{tabular}{|c|c|c|}
\hline & 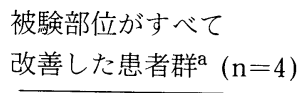 & $\begin{array}{l}\text { 非改善部位を有する } \\
\text { 患者群 }{ }^{b}(n=11)\end{array}$ \\
\hline $\mathrm{Av}$ & $36.5 \pm 12.6^{c}$ & $106.0 \pm 26.8$ \\
\hline $\mathrm{Aa} 2$ & $315.2 \pm 138.0$ & $553.5 \pm 454.6$ \\
\hline Aa 3 & $297.8 \pm 69.9$ & $360.0 \pm 161.9$ \\
\hline $\mathrm{Ec}$ & $157.7 \pm 33.2$ & $159.1 \pm 44.6$ \\
\hline $\mathrm{Fn}$ & $67.2 \pm 11.4$ & $58.2 \pm 14.8$ \\
\hline $\mathrm{Bg}$ & $209.3 \pm 37.8$ & $446.2 \pm 127.4$ \\
\hline $\mathrm{Bi}$ & $39.5 \pm 9.3$ & $68.8 \pm 13.4$ \\
\hline
\end{tabular}

a : すべての被験部位において GI, BP, PD のうち 2 つ以上 の指数が改善した患者

${ }^{\mathrm{b}}$ : GI, BP, PD のうち 2 つ以上の指数が改善しなかった 部位を 1 つまたは 2 つ口腔内に有する患者 ${ }^{c}$ : 抗体価の平均値士標準誤差

よび抗 Ec 血清と B. ureolyticus の組み合わせだけであ った。B. ureolyticus は以前に Bacteroides corrodens と して Ec と共に同種の菌として分類されていた $\left.{ }^{33}\right)$ が，こ のうち偏性嫌気性でウレアーゼ陽性の群を B. ureolytic$u s$ と命名した ${ }^{34)}$ ものであり， Ec との閒に共通抗原を有 していると推測される。

Bonta ら ${ }^{35)}$ は Aa の検出に, また Slots ら ${ }^{36)}$ は Aa と $\mathrm{Bg}$ の検出に, 間接螢光抗体法および培養法の両者を比 較検討した結果, 間接螢光抗体法はこの 2 菌種の検出に あたって迅速かつ信頼できる方法であると報告してい る。間接螢光抗体法によるプラーク中の特定細菌の検出 は，他菌種に対する交差反応の抑制と同一菌種内の異な った菌株を幅広く検出できるように今後一層の改良を加 えることによって，歯周ポケット内細菌に対する一次的 な臨床検査法として広く用いられると思われる。

Moore ら ${ }^{37)}$ の分離培養法によると, Actinomyces 属は 歯周炎患者から採取した歯肉縁下プラークの全分離菌中 $10.5 \%$ を占めており, 健常者の歯肉溝プラークでは全分 離菌の $35 \%$ に相当していたと報告している。本研究で 用いた抗 Av 血清は, A. naeslundii と交差反応を示し, プラーク中に Av 以外の Actinomyces 属が存在してい た場合, これらとも若干の交差性を示すものと推測され る。本研究における Av の初診時検出率は $1.32 \%$ であ り，成人性歯周炎患者の歯肉縁下プラーク中における $\mathrm{Av}$ の検出率が約 $3 \%$ であったという Loesche ら ${ }^{38)}$ の報 告よりも低い值を示した。Moore らおよび Loesche ら は，歯肉縁下プラークの採取をスケーラーまたはキュレ ットを用いて行っており，この採取法は，本研究のよう 
にペーパーポイントを用いて歯肉縁下細菌叢を採取した 場合と比較して, 歯面付着性プラークの回収率が高くな ると推測される。そして, Av は歯肉溝および歯周ポケ ット内において歯面付着性プラークを構成する細菌の一

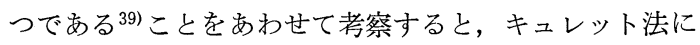
より歯肉縁下プラークを採取した場合には，同一ポケッ トに対してペーパーポイント法を用いる場合よりも Av の検出率が高くなると推測される。さらに, 間接螢光抗 体法による特定細菌の検出率は, 位相差顕微鏡下で観察 される総ての細菌に対する特定細菌の割合であるため, 培養できる細菌総数に対する特定細菌の割合として表現 される培養法による検出率よりも, 通常, 低い数值であ ることも本研究において Av の検出率が低い值を示した 理由と考えられる。

被験部位に扔ける Av の検出率と初診時の臨床指数と の関連性を検討した結果，いずれも有意差はないものの P1I が大きい群および PD が浅い群では，それぞれ P 1I が小さいおよび PD が深い場合よりも，Av の検出 率が高い傾向を示した（表 7 䇽よび 10)。Av は歯肉縁上 プラーク中に高い比率で存在すること ${ }^{40,41)}$ や，歯周治療 後の患者より採取した歯肉縁下プラーク中に占める比率 が未治療の歯周炎患者よりも高いこと保が報告されてい る。また, Av は S. sanguis とともに, プラーク形成の ごく初期段階に関与すること ${ }^{42)}$ などを考慮に入れると， Av は歯周炎罹患部よりも歯肉炎において主要な病因的 役割を果たす菌種であるのかもしれない。

本研究では, 初期治療を行うことによって Av の検出 率は $2.13 \%$ に上昇していた（表 4 ）。検出部位率におい ても, 他の菌種は初期治療によって検出部位率が減少し たのに対し，Av の検出部位率はほとんど変化しなかっ た。これらの結果注, 通性嫌気性菌の占める比率が高く, 偏性嫌気性菌およびスピロヘータの比率が低いことが歯 周疾患と関連性を持たないプラークの特徴のひとつであ るという Loesche ら ${ }^{38,43)}$ の結果と同じ傾向を示してい る。

歯周炎患者と健常者の間には抗 Av 抗体価に差が存在 しなかったという報告 ${ }^{44,45) か ゙ あ る 。 ま た, ~ F a r i d a ~ ら ~}{ }^{46)}$ の 報告によると，歯周炎患者に抢ける Av に対する IgG 抗体価は, 有意差はないものの健常者よりも低い傾向を 示していた。一方, 本研究では歯周炎患者の初診時にお ける抗 Av 抗体価は健常者より有意に低かった（表 6 ）。 これは，健常者の歯肉縁上および歯肉縁下プラーク中に は歯周炎患者よりも多量の Av が存在する可能性を示唆 するとも考えられるが，他方では次のような仮説も考え
られる。すなわち, 歯面付着性歯肉縁下プラーク中に存 在する $\mathrm{Av}$ が, 健常者では接合上皮や歯肉溝上皮に近接 しているため抗原刺激となるが, 歯周炎患者の歯周ポケ ット内では多量に非付着性歯肉縁下プラークが存在する ため Av がポケット上皮に接する機会が少なく, Av に よる抗原刺激作用が発動しにくいのかもしれない。

初期治療後の血清抗体価の測定結果では, 特定細菌の 中で Av に対する抗体価のみが上昇していた（表 6)。初 期治療によって Av の検出率は上昇したが, 歯周ポケッ ト内に存在する総菌数を測定することは非常に困難であ るために, Av の菌数が増加していたかどうかは定かで はない。実際には, 初期治療により総菌数が減少してい るために, Av の絶対数も減少していた可能性が考えら れ, 初期治療後にみられた抗 $\mathrm{Av}$ 抗体価の上昇が歯肉縁 上抢よび縁下プラーク中の $\mathrm{Av}$ 量の増加による結果であ るとは断定できない。むしろ, 初期治療の結果プラーク 中において Av が他の特定細菌よりも高い比率を占めた ことにより，Av が宿主に対して抗原刺激作用を加えた のではないかと推測される。本研究では行わなかった が, ペーパーポイントによって採取されたプラーク中の 総菌数を測定することによって, 歯周ポケット内の総菌 数, さらに各特定細菌の絶対数をある程度予測すること が今後の研究において必要であると考えられる。

Fn は, 初診時において 97 部位中 36 部位から検出さ れ, その平均検出率は $0.24 \%$ であった。この検出率は, Fn が歯周炎患者の病変部からの全分離菌 2,305 株中の $8.2 \%$ を占めたという Moore ら ${ }^{37)}$ の報告や, プラーク 細菌中の約 $4 \%$ を占めたといら Loesche ら ${ }^{38)}$ の報告と は異なっている。Tanner ら ${ }^{177}$ は, Fusobacterium 属は歯 周炎患者の歯肉縁下プラークから最も頻繁に分離同定さ れるが, 本菌は形態学的ならびに生理学的に非常に多様 であると述へている。また, ELISA 法を用いて IgG 抗 体価を測定した Tolo ら ${ }^{47)}$ の報告によれば, 2 株の Fn を 含む 3 株の Fusobacterium 属に対する抗体価のうち, 健 常者より有意に高い值を示したのは 1 株だけであり, この結果は Fusobacterium 属について徹底した分類学的 検討を加える必要性を示すものであると述べている。今 回作製した Fn の 1436 株に対するウサギ抗血清と, 1436 株以外の Fn の菌株との交差性を螢光抗体法で確認した 結果, Fn の 325 株のみが菌の形態が判断できる程度の 螢光を発したものの, 他の株は全くの陰性ではないが, 菌の輪郭が不明膫であり陽性菌とは明らかに異なる螢光 発色を示した（表 2)。本研究で Fn の検出率が従来の報 告よりも低かった理由としては, $\mathrm{Av}$ の検出率の差に関 
する考察と同じく，歯肉縁下プラークの採取方法による 差および培養方法と間接螢光抗体法による差に加えて, この Fn が有すると考えられる株特異的な性質により, 検出率に大きな差異が生じたものと思われる。したがっ て, 今後の研究では Fn 種に属する菌株を幅広く検出す るために, これらの菌株に共通する菌体抗原を用いて抗 血清を調製するか, あるいは数種類の菌株に対する抗血 清を混合した抗血清標品を用いてプラーク細菌を検索す る必要があらう。

Mandell ら ${ }^{48,49}$ は, 限局型若年性歯周炎患者のポケッ 卜内細菌を経時的に検討した結果, Ec は病変活性部位 での検出率が病変不活性部位よりも有意に高いと報告し て抢り, Tanner $5^{50)}$ は, 進行性歯周炎の病変活性部位 および非活性部位における $\mathrm{Ec}$ の平均検出率はそれぞれ $2.4 \%$ と $2.0 \%$ であり, 多くの患者では活性部位の検出 率が非活性部位よりも有意に高いが，非活性部位でも高 い值を示す患者も存在したと述べている。しかしなが ら, 本研究では Ec の検出率は非常に低く (表 4), 特異 抗体価は健常者と比較して有意差はなかった（表 6)。ま た, 炎症程度が高い部位と低い部位の間, 初期治療によ り改善が認められた部位と認められなかった 部位の間 で，Ec の検出率に有意差はなかった。今回作製した抗 Ec 血清は，供試した Ec のすべての株と反応性を示し， 検出可能な菌株の範囲が広いことが示唆された。したが って, 細菌の検出方法が異なることや, 患者の年齢, 病 型が珙なることが結果にこのような差が生じた理由と考 えられるが，口腔内における Ec の分布に人種間で差が あるか否かの検索が必要であるかもしれない。

Aa が限局型若年性歯周炎の病因に関係していること を示唆する報告は多い。Slots ら ${ }^{14)}$ は，正常な歯肉溝と 比較して限局型若年性歯周炎患者の歯周ポケットから Aa が多数検出されたと述べており，Zambon ら ${ }^{51)}$ 同 様の結果を得ている。また, 限局型若年性歯周炎患者の

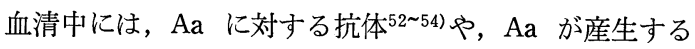
leucotoxin ${ }^{55,56)}$ を中和する抗体 ${ }^{57,58)}$ が存在することが 報告されている。一方, 限局型若年性歯周炎患者におけ る $\mathrm{Aa}$ の検出率がきわめて低かったといら報告 ${ }^{38,59)}$ もあ り, $\mathrm{Aa}$ の限局型若年性歯周炎における役割についての 完全な意見の一致は得られていない。

Zambon ら ${ }^{30,511}$ は Aa を $\mathrm{a}, \mathrm{b}$ および $\mathrm{c}$ の血清型に分 類し, 歯周炎患者および健常者の口腔内からは主にタイ プa と b が分類され, 中でも限局型若年性歯周炎患者か らはタイプbが多く検出されたと述べている。この報告 を参考にして, 本研究では Aa の ATCC 29522 株 (血清
型 b) および ATCC 29523 株（血清型 a) に対する抗血 清を用いて実験を行った結果, 被験部位からタイプ bは 全く検出されず，タイプ a の検出率も非常に低い值とな った（表 4)。一方，初診時における患者血清抗体価は， タイプ $\mathrm{a}$ および $\mathrm{b}$ 共に有意差はないものの健常者よりも やや高い傾向を示し，タイプa に対する抗体価は初期治 療を行うことによって有意に減少した（表 6 )。

このように, 本研究において Aa が歯周病変部局所か らほとんど検出されなかったにもかかわらず，Aa に対 しある程度の血清抗体価が検出された理由として, 以下 のことが推測される。すなわち，1）今回は, 患者の総て のポケットから試料を得ていないため, Aa が存在する 部位を逃した可能性, 2) タイプ c の菌が被験者の口腔内 に存在しており, ELISA 法によって, タイプ c の Aa が 保有している, タイプa あるいはタイプ b と共通した抗 原に対する抗体を検出した可能性, 3) 分類学上 Aa に近 い他の菌種に対する抗体を検出した可能性，などが考え られる。

扇ら ${ }^{60)}$ の最近の報告によると, 歯周炎に罹患している 32 部位から分離された 157 株の $\mathrm{Aa}$ のうち, 74 株がタイ プ c で, 10 株がタイプ a, そして残りの 73 株がいずれの 血清型にも属さず, タイプ b は全く検出されなかった。 また, 渡辺ら ${ }^{61)}$ は $\mathrm{Aa}$ の膜画分と可溶性画分を用いて歯 周炎患者の血清 IgG 抗体価を測定した結果, 20 歳代の 高度歯周炎患者においてタイプ $\mathrm{c}$ に対する抗体価が高か ったと報告している。本研究で Aa の検出に用いた抗 Aa 2 および抗 Aa 3 血清は, 免疫原とした菌株と異なる タイプの Aa の菌株で吸収し特異性を高めた抗血清であ るため, タイプ cの Aa を検出できなかったと推測され る。一方, 血清抗体価の測定にはそれぞれ抗原とした Aa の菌株の全菌体を用いたので, タイプ c との共通抗 原が存在し, タイプ c に対する抗体を含めて検出した結 果となったものと考えられる。今後, タイプ cの Aaに 対する抗血清を用いて, 歯周炎患者の歯肉縁下プラーク を全顎的に検索し, 口腔内に存在する Aa と血清抗体価 の上昇を示す $\mathrm{Aa}$ の血清型が一致するか否かを検討する 必要性がある。

Pott ら ${ }^{31,32)}$ は . aphrophilus は Aa と約 $35 \%$ の DNA 相同性を示し, この両者が近い菌種であると報告 している。Genco ら ${ }^{53)}$ は, H. aphrophilus および $H$. influenzae と Aa に対する抗体価の相関性が低く, Haemophilus 属の菌で吸收操作を行って抗 Aa 抗体価を 測定しても, 減少率は少ないと述べている。本研究では, 結果の項には示していないが, 抗 Aa 2 血清をS. sanguis 
で吸収すると，タイプ b に対する抗体価が OD 值で約 $13 \%$ しか減少しなかったのに対し, H. aphrophilus で吸 収した場合 $41 \%$ 減少する結果を得た。したがって, 本研 究の被験者のプラーク中に H. aphrophilus が存在して いたなら，Aa に対する IgG 抗体価になんらかの影響を 与えると推測される。この問題点を解決する方法として は, Aa 特異抗原を精製して, これに対する血清抗体価 を測定すること， あるいは $\mathrm{Aa}$ と共通した抗原を有する と判明している菌株を用いて, 被験血清をあらかじめ吸 収した後，抗 Aa 抗体価を測定することが考えられる。 後者では, 吸収に用いる細菌の口腔内における存在もあ わせて検索しなければならないであろう。

黒色色素産生性 Bacteroides である $\mathrm{Bg}$ と $\mathrm{Bi}$ の初診 時における検出率は，それぞれ $3.5 \%$ および $1.26 \%$ で あったが，初期治療後にはそれぞれ $0.66 \%$ および 0.63 \%と，いずれも有意に減少した（表 4)。また，初診時に おける臨床所見の違いによって被験部位を 2 群に分類 し，それぞれにおける検出率を比較した結果，GI, BP お よび PDの各項目において, 辺縁歯肉の炎症あるいは歯 周組織破壊の程度が強い部位では, 臨床的に炎症が軽度 と判断された部位よりも $\mathrm{Bg}$ の検出率が有意に高い值を 示した（表 8,9 および 10)。骨吸收率でも同様の傾向が みられたものの, P 1 I すなわち歯肉縁上プラークの量が 異なっても， Bg の検出率に差は認められなかった（表 7)。これは, 歯周炎罹患部位では正常な歯肉溝と比較し て黒色色素産生性 Bacteroides, 特に Bg が高頻度に検出 されたという Spiegel ら ${ }^{62)}$ の報告や，PD および GI が 高い值を示す部位には Bacteroides 属の細菌が高い比率 で存在し, その中では Bg が優性であったという White ら11)の結果と同じ傾向を示すものであった。

White ら ${ }^{11)}$ にると, ポケット深さが $6 \mathrm{~mm}$ 以上を 示寸部位での Bg の検出率は $27 \%$ であり, Spiegel ら ${ }^{62)}$ は, 中等度の炎症を示す部位における $\mathrm{Bg}$ の検出率は $12.1 \%$ であったと報告している。これらの結果と本研究 との間で Bg の検出率に大きな差が存在する理由とし て, 対象とした被験者の病態がそれぞれの研究において 異なっている可能性の他に, 間接螢光抗体法と培養法と いう検出方法の違いによるものと考えられる。しかしな がら, 検出率に差があるものの, 歯周炎による組織破壊 の程度が臨床的に高いと評価された部位では, 低い部位 と比較して Bg の検出率が有意に高かったことから, Bg は歯周病の診断に際して一つの指標となり得る細菌であ る可能性が示唆された。

斉藤ら ${ }^{63)}$ は, 歯周病変部から分離された黒色色素産生
性 Bacteroides のうち, Bi の検出率がきわめて高く, Bg の検出率は $1.1 \%$ と低加たと述べており, Zambon $ら^{64)}$ も, 成人性歯周炎患者から Bi が優勢な菌として検 出されたと述べている。さらに, Bi と妊娠性歯周炎 ${ }^{65)}$, 急性壊死性歯肉炎 ${ }^{66)}$ との関連性が報告されており, Bi が 歯肉の炎症を誘発できることが示唆されている。一方, $\mathrm{Bi}$ が健全な歯肉溝からも分離されること ${ }^{62)}$ や, 歯周炎の 進行に伴い $\mathrm{Bg}$ の検出率が高くなり, Bi の検出率は低下 するという報告 ${ }^{17)}$ むり, Bi と歯周炎との関連性は明確 ではない。本研究では, $\mathrm{Bg}$ と Bi の初診時における検出 部位率にほとんど差はみられなかったが, Bi の検出率は $\mathrm{Bg}$ の検出率よりも低かった。また, 臨床指数によって 被験部位を歯周炎の程度が強い群と弱い群に分類して も，それぞれにおける Bi の検出率に有意差はなかった。 さらに，患者群と健常者群との間で抗 Bi 抗体価に有意

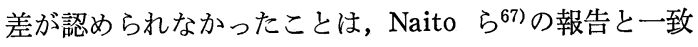
する。これらの結果は, Bi が歯周炎患者に限らず歯周組 織がある程度健康なヒトの口腔内にも広く分布すること を示唆しているのかもしれない。

本研究で, Bg に対する患者血清抗体価が健常者より も有意に高い值を示したことは, 成人性歯周炎患者で抗 Bg 抗体価が上䄯していたという他の報告 $12,44,67,68)$ と一 致している。この抗 $\mathrm{Bg}$ 抗体価は, 他報 ${ }^{62 ~ 70)}$ でも述べら れているように, 初期治療後に有意な低下を認めたが, 依然として健常者の血清抗体価よりも高い值に留まって いた (表 6)。この抗 Bg 抗体価の変動は, 歯肉縁下プラ 一ク中における $\mathrm{Bg}$ の変動と関連性があるように思われ る。すなわち, ポケット内の $\mathrm{Bg}$ 量が初期治療により減 少したことにより, 抗 $\mathrm{Bg}$ 抗体価が低下したものと考え られる。同様に，初期治療後における抗 Bi 抗体価の有 意な減少も, $\mathrm{Bi}$ 量の減少を反映するものであろう。一般 的に特異抗体は, 抗原による刺激から約 1 力月後に検出 され，抗原が存在していれば抗体価は高い值を持続し， 抗原を除去した後も抗体価の減少は緩慢である71)。患者 群の初期治療後の抗 Bg 抗体価が健常者のものより有意 に高かったのはこの機構のあらわれであろう。

初期治療による各種臨床指数の改善群と非改善群との 間に, 初診時の特定細菌の検出率に有意差は認められな かった（表 12〜15）。つまり，初期治療により臨床指数 が改善しなかった部位は, 改善した部位よりも疾病活性 度が高いと仮定し, この活性度を初診時の細菌検出率で 予測しょうとする試みは, 本研究で用いた特定細菌では 達成されなかった。一方, BP および PD 非改善群では, 初期治療後の $\mathrm{Bg}$ の検出率が改善群よりも有意に高かっ 
た（表 18 および 19）。さらに，複数の臨床指数が改善し なかった部位では, 改善した部位と比較して，初期治療 後も $\mathrm{Bg}$ が高い比率で存在していた。このような結果は， 初期治療後の $\mathrm{Bg}$ の検出率が再評価後の歯周治療やメイ ンテナンス期における処置方針を決定する際に指標の一 つとなることを示唆しているのかもしれない。

Socransky ら ${ }^{72 \sim 74)}$ は，歯周病は持続的に，また緩やか に進行していくのではなく, 活動期と静止期を繰り返し ながら進行していくものであり ${ }^{75)}$, アタッチメントレベ ルを測定することによってこの活動期を探知した場合, 従来から用いられている臨床指数はこの活動期を予知す る指標とはならなかったと述べている76)。本研究では, 歯周初期治療に対する反応性に基づいて被験部位の疾病 活性度を推定し，各特定細菌との関連性を検討した。す なわち, 初期治療を行ったにもかかわらず炎症の程度が 改善されない部位は, 疾病活性度が高かったと仮定して 実験を行った。この方法は, 現在行われている歯周病の 治療体系が, 初めに原因因子の除去を基本とした初期治 療を施した後, 再評価を行って, 各患者の確定的歯周治 療へと進めていくため, 歯周炎患者の治療を阻害するこ となく臨床研究を遂行できる利点がある。また，患者を 長期間にわたり未治療のまま監視する必要がなく, 直ち に治療体制に入れるという点で, 他の研究者が歯周病患 者を未治療のまま病態の推移を測定していく際に苦虑し ている倫理的問題を考慮しなくてもよい。しかしなが ら, 治療行為を伴った研究方法には, 治療方法が同一で あっても被験者および被験部位に対して同じ刺激を与え ることにはならないという問題点がある。すなわち，1) 刷掃指導によって被験者が獲得した刷掃方法および能力 に被験者間で差がある，2）ポケットの形態や, 歯列不正 などといった歯周組織の形態学的な差や，前歯部と曰歯 部による違いが, 被験部位に対する治療器具の到達度に 差異を生じ, 除去可能な歯肉縁下プラーク量が異なる, といった因子が治療効果を評価する際に影響を与えるで あろう。また，歯周ポケット内の細菌を可及的に除去す ることは, 当然のことながら歯肉縁下細菌叢に多大な影 響を与え, 治療効果としで炎症状態の改善が大部分の被 験部位でみられるため, Socransky らが述べるところの 疾患の活動期, すなわち歯周炎が急速に進行する時期を 捕らえにくいことも問題点の一つであろう。したがっ て, 本研究での検定系を用いて, 倫理的に許される期間 内で未治療のまま, 治療行為による因子を排除した条件 下で疾病活性度を検討することも今後の課題の一つと考 えられる。
一般に，常在菌などによって污染されていない患者材 料, たとえば血液, 髄液などから検出された細菌は比較 的容易に病原菌と断定することができる。しかし，歯周 病のように多数の口腔内常在菌が存在する環境下での感 染症の場合には, Socransky77) が示した判断基準，すな わち 1）同じ微生物が疾病部位に高率にみられ，健全部 位にはみられないか低率である，2）その微生物を排除す ると疾病の進行が停止する，3）その微生物に対し宿主が 特異的免疫応答を示す, 4) 実験動物に類似の疾病を起こ すことができる，5）病原性を発揮する特殊な性質を有す る, などに基づいて病原菌が推定される。本研究では, 検討した特定細菌の中で, $\mathrm{Bg}$ がこれらの基準のうちの 臨床分野における 1)〜3）の条件をほぼ満たしていた。

初期治療により被駼部位のすべてが臨床的に改善した 患者群と, 口腔内に 1 部位でも非改善部位を有した患者 群の閒に特定細菌に対する IgG 抗体価に違いがみ.られ るか否かを検討した結果，いずれの特定細菌に対する抗 体価に関しても有意差は認められなかった（表 22 お び 23)。非改善部位が認められた患者の場合でも，同一 口腔内の他の多くの部位は臨床的に改善しており, 初期 治療を行っても口腔内のほとんぞ総ての部位が非改善と いうような患者は本研究では認められなかったことがこ の結果をもたらした理由の一つと考えられる。さらに, 両群ともに抗 $\mathrm{Aa} 3$, 抗 Bg 扰よび抗 Bi 抗体価の初期治 療による減少傾向が認められたことも，患者単位でみる と被験者全員が初期治療に対して反応性を示したことを 表していると考えられる。一般に，歯周炎は部位によっ て病変の程度やプラーク細菌叢が異なるため, 患者の血 清抗体価を単独で診断指標に用いた場合, 部位特異性は 表現しがたいであろう。しかしながら，本研究でみらられ た初期治療後における抗 $\mathrm{Bg}$ 抗体価の減少は，ポケット 内の $\mathrm{Bg}$ が減少した結果生じたものと推察され, 抗 $\mathrm{Bg}$ 抗体価と Bg の検出率との関連性が示唆された。このよ らに歯周炎において, ある種の細菌に対する血清抗体価 を測定することは，補助的な診断法として利用できるの かもしれない。

本研究により，歯肉縁下プラーク中における $\mathrm{Bg}$ の検 出率が歯周炎の診断指標の一つとなり得る可能性が示唆 された。また, 実験方法に加えるべきいくつかの改良点 が明らかとなった。今後, メインテナンス期の患者, あ るいは未治療の患者のアタッチメントレベルを可能な期 間内で経時的に測定し，治療行為による影響を与えずに 歯周組織局所の疾病活性度を評価するといった多角度か らの検討を考えている。そして，歯周ポケット内細菌の 
検索に，総菌数の算出および暗視野顕微鏡によるスピロ ヘータや運動性桿菌の検出を加え, 一方で歯周組織局所 における生体の反応性, 例えば歯肉瑇浸出液中の炎症义 ディエーターの検索を行い，原因因子と生体反応の両面 から歯周疾患を解析する事は興味深い研究方法と考えら れる。

\section{結＼cjkstart論}

間接螢光抗体法を用いた特定細菌検出系と, 特定細菌 に対する血清抗体価を ELISA 法によって測定する系を 確立して, 歯周炎患者の初期治療前後における歯肉縁下 細菌叢の検索および血清中の特異 $\operatorname{IgG}$ 抗体価の測定を 行い,これらと臨床指数との関連性を検討した結果, 以 下の所見を得た。

1. 間接螢光抗体法によるポケット内細菌の定量法は 比較的高い特異性を有し, 臨床研究に際して有用な手段 であることが示唆された。

2. 初診時の歯周ポケットから $\mathrm{Av}, \mathrm{Bg}$ および $\mathrm{Bi}$ が 高頻度に検出された。このうち, Bg および Bi は初期治 療後に検出率および検出部位率が有意に減少したが, Av の検出率は増加する傾向にあった。

3. 初診時に扔ける患者血清中の抗 Bg 抗体価は, 健 常者よりも有意に高く, 逆に抗 $A v$ 抗体価は有意に低い 值を示した。抗 Av 抗体価以外は初期治療によって減少 し, 特に Aa 3, Bg および Bi に対する抗体価は有意に 減少した。しかし初期治療後の抗 $\mathrm{Bg}$ 抗体価は依然とし て健常者よりも有意に高い值を示した。

4. 初診時における GI, BP あるいは PD の值によっ て, 歯周組織の炎症や破壊の程度が大きいと評価された 部位には，その程度が小さいと評価された部位よりも $\mathrm{Bg}$ が有意に高い比率で存在していた。しかし, 被験部 位の P 1I の大小によって細菌検出率の違いを検討して も，いずれの細菌についても有意差はなかった。

5. 被験部位を初期治療によって臨床所見が改善した 部位と改善しなかった部位に分類して各特定細菌の検出 率を比較した結果, BP 非改善群および PD 非改善群で は, 改善群よりも有意に高い比率で $\mathrm{Bg}$ が初期治療後の ポケットに残存していた。一方, 初期治療による治療効 果の優劣は, 初診時における各特定細菌の検出率で予測 することはできなかった。

6. 被験部位を GI, BP および PD のうち初期治療に より 2 つ以上改善した群と，2つ以上非改善であった部 位に分けて比較した場合, 初診時の細菌検出率に有意差
は認められなかったが, 非改善群の初期治療後の $\mathrm{Bg}$ 検 出率は改善群よりも有意に高い值を示した。

以上の結果より, 歯周治療に際して, 歯肉縁下プラー ク中の $\mathrm{Bg}$ の検出率と抗 $\mathrm{Bg}$ 抗体価が診断指標の一つと なり得る可能性が示唆された。

\section{謝 辞}

稿を終えるにあたり，御指導と御校閲を賜りました口腔治療 学講座岡田 宏教授に心から感謝いたします。また, 本研究の 遂行にあたり直接御指導を頂きました口腔治療学講座恵比須繁 之助教授に深く感謝いたしますとともに，適切な御助言を戴き ました口腔治療学講座木村重信博士に深謝いたします。

最後に, 本研究に対してさまざまな御援助と御協力を戴きま した口腔治療学教室員の皆㥞に厚く御礼申し上げます。

\section{文献}

1) Youmans, G.P. : Host-bacteria interactions : Immunologic internal defense mechanisms, In Youmans, G.P., Paterson, M.D. and Sommers, H.M. (ed.), The biologic and clinical basis of infectious diseases, W.B. Saunders Company, Philadelphia, 1985, 25-29.

2) Ellison, S.A. : Oral bacteria and periodontal disease. J. Dent. Res., 49 : 198-201, 1970.

3) Keyes, P.H. : Are periodontal pathoses caused by bacterial infections on cervicoradicular surfaces of teeth ? J. Dent. Res., $49: 223-228$, 1970.

4) Socransky, S.S. : Relationsip of bacteria to the etiology of periodontal disease. J. Dent. Res., 49 : 203-222, 1970.

5) Kelstrup, J. and Theilade, E. : Microbes and periodontal disease. J. Clin. Periodontol., 1 : 15-35, 1974.

6) Slots, J. : Microflora in the healthy gingival sulcus in man. Scand. J. Dent. Res., $85: 247-$ 254, 1977.

7) Slots, J. : The predominant cultivable microflora of advanced periodontitis. Scand. J. Dent. Res., 85 : 114-121, 1977.

8) Slots, J. : The predominant cultivable organisms in juvenile periodontitis. Scand. J. Dent. Res., 84 : 1-10, 1976. 
9) Newman, M.G. and Socransky, S.S. : Predominant cultivable microbiota in periodontosis. J. Periodont. Res., 12 : 120-128, 1977.

10) Newman, M.G., Socransky, S.S., Savitt, E.D., Propas, D.A. and Crawford, A. : Studies of the microbiology of periodontosis. J. Periodontol., 47 : 373-379, 1976.

11) White, D. and Mayrand, D. : Association of oral Bacteroides with gingivitis and adult periodontitis. J. Periodont. Res., 16 : 259-265, 1981.

12) Mouton, C., Hammond, P.G., Slots, J. and Genco, R.J. : Serum antibodies to oral Bacteroides asaccharolyticus (Bacteroides gingivalis) : relationship to age and periodontal disease. Infect. Immun., 31 : 182-192, 1981.

13) Ebersole, J.L., Taubman, M.A., Smith, D.J. and Frey, D.E. : Human immune responses to oral microorganisms : patterns of systemic antibody levels to Bacteroides species. Infect. Immun., $51:$ 507-513, 1986.

14) Slots, J., Reynolds, H.S. and Genco, R.J. : Actinobacillus actinomycetemcomitans in human periodontal disease : a cross-sectional microbiological investigation. Infect. Immun., 29 : 10131020, 1980.

15) Ebersole, J.L., Taubman, M.A., Smith, D.J., Genco, R.J. and Frey, D.E. : Human immune responses to oral microorganisms I. Association of localized juvenile periodontitis (LJP) with serum antibody responses to Actinobacillus actinomycetemcomitans. Cli. exp. Immunol., 47 : 43-52, 1982.

16) Listgarten, M.A., Lai, C.-H. and Evian, C.I. : Comparative antibody titers to Actinobacillus actinomycetemcomitans in juvenile periodontitis, chronic periodontitis and periodontally healthy subjects. J. Clin. Periodontol., $8:$ 155-164, 1981.

17) Tanner, A.C.R., Haffer, C., Bratthall, G.T., Visconti, R.A. and Socransky S.S. : A study of the bacteria associated with advancing periodontitis in man. J. Clin. Periodontol., $6: 278$ 307, 1979.

18) Lindhe, J., Liljenberg, B. and Listgarten, M. :
Some microbioloical and histopathological features of periodontal disease in man. J. Periodontol., 51 : 264-269, 1980.

19) Evian, C.I., Rosenberg, E.S. and Listgarten, M.A. : Bacterial variability within diseased periodontal sites. J. Periodontol., 53 : 595-598, 1982.

20) Rosenberg, E.S., Evian, C.I. and Listgarten, M.A. : The composition of the subgingival microbiota after peri- odontal therapy. J. Periodontol., 52 : 435-441, 1981.

21) Syed, S.A., Morrison, E.C. and Lang, N.P. : Effects of repeated scaling and root planing and/or controlled oral hygiene on the periodontal attachment level and pocket depths in beagle dogs II. Bacteriological findings. J. Periodont. Res., 17 : 219-225, 1982.

22) Singletary, M.M., Crawford, J.J. and Simpson, D.M.:Dark-field microscopic monitoring of subgingival bacteria during periodontal therapy. J. Periodontol., 53 : 671-681, 1982.

23) Ebersole, J.L., Taubman, M.A., Smith, D.J. and Haffajee, A.D. : Effect of subgingival scaling on systemic antibody responses to oral microorganisms. Infect. Immun., $48: 534-539$, 1985.

24）岡村和則, 永井 淳, 熊澤 寛, 杉山雅昭, 水島 ゆみ, 光田由可, 高柴正悟, 栗原英見, 野村慶雄, 村山洋二：歯周病関連細菌に対する血清 $\operatorname{IgG}$ 抗 体 第 2 報 歯周病治療に伴う血清 $\operatorname{IgG}$ 抗体の 変動. 日歯周誌, $29: 146-154,1987$.

25) Mandel, I.D. : Summary of conference and perspectives for the future, In Genco, R.J. and Mergenhagen, S.E. (ed.), Host-parasite interactions in periodontal disease, American Society for Microbiology, Washington D.C., 1982, 404-409.

26) Silness, J. and Löe, H. : Periodontal disease in pregnancy II . correlation between oral hygiene and periodontal condition. Acta Odont. Scand., 22 : 121-135, 1904.

27) Löe, H. and Silness, J. : Periodontal disease in pregnancy I. prevalence and severity. Acta Odont. Scand., 21 : 533-551, 1963. 
28) Schei, O., Waerhaug, J., Lovdal, A. and Arno, A. : Alveolar bone loss as related to oral hygiene and age. J. Periodontol., 30:7-16, 1959.

29）木村重信：多形核白血球による口腔放線菌食作用 に関する研究一特に免疫血清のオプソニン効果と 菌表層成分の関与一. 阪大歯学誌, $28: 62-78$, 1983.

30) Zambon, J.J., Slots, J. and Genco, R.J. : Serology of oral Actinobacillus actinomycetemcomitans and serotype distribution in human periodontal disease. Infect. Immun., $41: 19-27,1983$.

31) Potts, T.V. and Berry, E.M. : Deoxyribonucleic acid-deoxy ribonucleic acid hybridization analysis of Actinobacillus actinomycetemcomitans and Haemophilus aphrophilus. Int. J. Sys. Bact., $33:$ 765-771, 1983.

32) Potts, T.V., Zambon, J.J. and Genco, R.J. : Reassignment of Actinobacillus actinomycetemcomitans to the genus Haemophilus as Haemophilus actinomycetemcomitans comb. nov. Int. J. Sys. Bact., 35 : 337-341, 1985.

33) Eiken, M. : Studies on an anaerobic, rodshaped, Gram-negative microorganism: Bacteroides corrodens n. sp. Acta Path. Microb. Scand., 43 : 404-416, 1958.

34) Jackson, F.L. and Goodman, Y.E. : Bacteroides ureolyticus, a new species to accommodate strains previously identified as "Bacteroides corrodens", anaerobic. Int. J. Sys. Bact., 28 : 197-200, 1978.

35) Bonta, Y., Zambon, J.J., Genco, R.J. and Neiders, M.E. : Rapid identification of periodontal pathogens in subgingival plaque : Comparison of indirect immunofluorescsnce microscopy with bacterial culture for detection of Actinobacillus actinomycetemicomitans. J. Dent. Res., 64 : 793-798, 1985.

36) Slots, J., Hafström, C., Rosling, B. and Dahlen, G. : Detection of Actinobacillus actinomycetemcomitans and Bacteroides gingivalis in subgingival smears by the indirect fluorescent-antibody technique. J. Periodont. Res., $20: 613-620$, 1985.

37) Moore, W.E.C., Ranney, R.R. and Holdman,
L.V. : Subgingival microflora in periodontal disease : cultural studies, In Genco, R.J. and Mergenhagen, S.E. (ed.), Host-parsite interaction in periodontal disease, American Society for Microbiology, Washington, D.C., 1982, 1326.

38) Loesche, W.J., Syed, S.A., Schmidt, E. and Morrison, E.C. : Bacterial profiles of subgingival plaques in periodotitis. J. Periodontol., 56 : 447-456, 1985.

39) Newman, M.G. and Saglie, F.R.: The role of microorganisms in periodontal disease, In Carranza Jr., F.A. (ed.), Glickman's clinical periodontology, W.B. Saunders Company, Philadelphia, 1984, 361-390.

40) Loesche, W.J. and Syed, S.A. : Bacteriology of human experimental gingivitis : effect of Plaque and gingivitis score. Infect. Immun., $21: 830-839,1978$.

41) Syed, S.A. and Loesche, W.J. : Bacteriology of human experimental gingivitis : effect of plaque age. Infect. Immun., $21: 821-829,1978$.

42) Socransky, S.S., Manganiello, A.D., Propas, D. Oram, V. and van Houte, J. : Bacteriological studies of developing supragingival dental plaque. J. Periodont. Res., 12 : 90-106, 1977.

43) Loesche, W.J. : Chemotherapy of dental qlaque infections. Oral Sci. Rev., $9: 65-107,1976$.

44）永井 淳, 岡村和則, 小林充治, 横山雅之, 熊澤 寞, 杉山雅昭, 栗原英見, 野村慶雄, 村山洋二 : 歯周病関連細菌に対する血清 IgG 抗体 第 1 報 歯周病の病状と IgG 抗体との相関. 日歯周誌, $29: 132-145,1987$.

45) Doty, S.L., Lopatin, D.E., Syed, S.A. and Smith, F.N. : Humoral Immune response to oral microorganisms in periodontitis. Infect. Immun., 37 : 499-505, 1982.

46) Farida, R., Marsh, P.D., Newman, H.N., Rule, D.C. and Ivanyi, L. : Serological investigation of various forms of inflammatory periodontitis. J. Periodont. Res., 21 : 365-374, 1986.

47) Tolo, K., Schenck, K. and Brndtzaeg, P. : Enzyme-linked immunosorbent assay for human IgG, IgA, and IgM antibodies to antigens from 
anaerobic cultures of seven oral bacteria. J. Immunol. Methods, 45 : 27-40, 1981.

48) Mandell, R. : A longitudinal microbiological investigation of Actinobacillus actinomycetemcomitans and Eikenella corrodens in juvenile periodontitis. Infect. Immun., $45: 778-780$, 1984.

49) Nandell, R.L., Ebersole, J.L. and Socransky, S.S. : Clinical immunological and microbiological features of active disease sites in juvenile periodontitis. J. clin. Periodontol., 14 : 534-540, 1987.

50) Tanner, A.C.R., Dzink, J.L., Ebersole, J.L. and Socransky, S.S. : Wolinella recta, Campylobacter concisus, Bacteroides gracilis, and Eikenella corrodens from periodontal lesions. J. Periodont. Res., 22 : 327-330, 1987.

51) Zambon, J.J., Christersson, L.A. and Slots, J. : Actinobacillus actinomycetemcomitans in human periodontal disease. Prevalence in patient groups and distribution of biotypes and serotypes within families. J. Periodontol., 54 : 707711, 1983.

52) Ebersole, J.L., Taubman, M.A., Smith, D. and Socransky, S.S. : Humoral immune responses and diagnosis of human periodontal disease. J. Periodont. Res., 17 : 478-480, 1982.

53) Genco, R.J., Zambon, J.J. and Murray, P.A. : Serum and gingival fluid antibodies as adjuncts in the diagnosis of Actinbacillus actinomycetemcomitans-associated periodontal disease. J. Periodontol., $56:$ 41-50, 1985.

54) Vincent, J.W., Suzuki, J.B., Falkler Jr., W.A. and Cornett, W.C. : Reaction of human sera from juvenile periodontitis, rapidly progressive periodontitis, and adult periodontitis patients with selected periodontopathogens. J. Periodontol., $56:$ 464-469, 1985.

55) Hammond, B.F. and Stevens, R.H. : Capnocytophaga and Actinobacillus actinomycetemcomitans : occurrence and pathogenic potential in juvenile periodontitis, In Genco, R.J. and Mergenhagen, S.E. (ed.), Host-parsite interaction in periodontal disease. American Society for Microbiology, Washington, D.C., 1982, 4661 ,

56) Baehni, P., Tsai, C.-C., McArthur, W.P., Hammond, B.F. and Taichman, N.S. : Interaction of inflammatory cells and oral microorganisms. VIII. Detection of leukotoxic activity of a plaque-derived Gram-negative microorganism. Infect. Immun., 24 : 233-243, 1979.

57) Tsai, C.-C., McArthur, P., Baehni, P.C., Evian, C., Genco, R.J. and Taichman, N.S. : Serum neutralizing activity against Actinobacillus actinomycetemcomitans leukotoxin in juvenile periodontitis. J. Clin. Periodontol., $8: 338-348$, 1981.

58) McArthur, W.P., Tsai, C.-C., Baehni, P.C., Genco, R.J. and Taichman, N.S. : Leukotoxic effects of Actinobacillus actinomycetemcomitans. Modulation by serum components. J. Periodont. Res., 16 : 159-170, 1981.

59) Okuda, K., Naito, Y., Ohta, K., Fukumoto, Y., Kimura, Y., Ishikawa, I., Kinoshita, S. and Takazoe, I. : Bacteriological study of periodontal lesions in two sisters with juvenile periodontitis and their mother. Infect. Immun., 45 : 118-121, 1984.

60）扇 正一, 鴨井久一: 歯周ポケットより分離され た Haemophilus actinomycetemcomitans の血清学 的検索. 日歯周誌, 30 : 秋季特別号 87,1988 .

61）渡辺幹一, 菅野寿一, 大橋正彦, 川浪雅光, 加藤 㜯, 吉村文信, 鈴木 武 : 歯周疾患患者の体液性 免疫応答に関する研究 1 . 若年者歯周 炎患者と Actinobacillus actinomycetemcomitans との関連 について. 日歯周誌, $29: 256-257,1987$.

62) Spiegel, C.A., Hayduk, S.E., Minah, G.E. and Krywolap, G.N. : Black-pigmented Bacteroides from clinically characterized periodontal sites. J. Periodont. Res., 14 : 376-382, 1979.

63）斉藤 正 : 歯周疾患病巣における黒色色素 産 生 Bacteroides の検出率と分離菌種. 日歯周誌，29: 1-11, 1987.

64) Zambon, J.J., Reynolds, H.S. and Slots, J. : Black-pigmented Bacteroides spp. in the human oral cavity. Infect. Immun., 32 : 198-203, 1981.

65) Kornman, K.S. and Loesche, W.J. : The sub- 
gingival microbial flora during pregnancy. J. Periodont. Res., 15 : 111-122, 1980.

66) Loesche, W.J., Syed, S.A., Laughon, B.E. and Stoll, J. : The bacteriology of acute necrotizing ulcerative gingivitis. J. Periodontol., $53: 223-$ 230, 1982.

67) Naito, Y., Okuda, K. and Takazoe, I. : Immunoglobulin G response to subgingival Gramnegative bacteria in human subjects. Infect. Immun., $45:$ 47-51, 1984.

68）堀野一人：Bacteroides, Actinobacillus に対する 歯周疾患罹患者の血清及び歯肉溝滲出液抗体価に ついて. 日歯周誌， $30: 452-465,1988$.

69）渡辺 久, 杉山栄一, 堀部元雄, 石川 烈: 初期 治療の歯周疾患関連菌に対する血清 IgG 抗体価 に及ぼす影響について。目歯周誌，28：631-638， 1986.

70) Vincent, J.W., Falker, Jr., W.A., Cornett, W.C. and Suzuki, J.B. : Effect of periodontal therapy on specific antibody responses to suspected periodontopathogens. J. Clin. Periodontol., $14:$ 412-417, 1987.

71) Chung, C.-P., Lee, Y.-K., Choi, S.-M. and Nisengard, R.J. : Antibodies to Actinobacillus actinomycetemcomitans in a Korean population.
J. Periodontol., 57 : 510-515, 1986.

72) Haffajee, A.D., Socransky, S.S. and Goodson, J.M. : Periodontal disease activity. J. Periodont. Res., 17 : 521-522, 1982.

73) Goodson, J.M., Tanner, A.C.R., Haffajee, A.D., Sornberger, G.C. and Socransky, S.S. : Patterns of progression and regression of advanced destructive periodontal disease. J. Clin. Periodontol., $9: 472-481,1982$.

74) Haffajee, A.D., Socransky, S.S. and Goodson, J.M. : Comparison of different data analyses for detecting changes in attachment level. J. Clin. Periodontol., 10 : 298-310, 1983.

75) Socransky, S.S., Haffajee, A.D., Goodson, J.M. and Lindhe, J.: New concepts of destructive periodontal disease. J. Clin. Periodontol., 11 : 21-32, 1984.

76) Haffajee; A.D., Socransky, S.S. and Goodson, J.M. : Clinical parameters as predictors of destructive periodontal disease activity. J. Clin. Periodontol., $10:$ 257-265, 1983.

77) Socransky, S.S. : Criteria for the infectious agents in dental caries and periodontal disease. J. Clin. Periodontol., 6 (no. 7 extra issue) : 16, 1979. 